\title{
ИЗ ИМЕННОГО УКАЗАТЕЛЯ \\ К «ЗАПИСНЫМ КНИЖКАМ» АХМАТОВОЙ
}

\author{
Р. Д. Тименчик \\ (Иерусалим)
}

Настоящая подборка является 33-й в ряду однотипных, кои мы перечислим:

I. История, культура, литература: К 65-летию С. Ю. Дудакова. Иерусалим: Hebrew University of Jerusalem, Center for Slavic Languages and Literatures, 2004. С. 221-234 (Баумволь Р. Л.; Вейнберг С.; Бен Ф.).

II. Quadrivium. К 70-летию проф. В. А. Московича. Иерусалим: Hebrew University of Jerusalem, Center for Slavic Languages and Literatures, 2006. С. 205-224 (Ависага; Галкин С. 3.; Лотова жена).

III. Стих, язык, поэзия: Памяти Михаила Леоновича Гаспарова. М.: Российский государственный гуманитарный университет, 2006. С. 614-639 (Бобров С. П.; Черубина де Габриак; Шенгели Г. А.).

IV. «Я всем прощение дарую...»: Ахматовский сборник. М.; СПб.: Альянс-Архео, 2006. С. 492-517 (Адалис А; Арбенина О. Н.; Аренс В. Е.; Гринвальд М. К.; Ефименко Т. П; Колесова Е. В; Лившиц Б. К.; Лозинская Т. Б.; Моравская М. Л.; Персиц Т. М.; Тальников Д. Л.).

V. Эткиндовские чтения. II-III. СПб.: Европейский университет в Санкт-Петербурге, 2006. С. 214-276 (Апт С. К.; Артемов А. Н.; Базилевский Н. Г; Барнс К.; Бланков Ж.; Блок Л. Д.; Бобович Г. А.; Богданова-Бельская П. О.; Большухин Ю. Я.; Ботвинник Н. Б.; Боффа Л.; Буланже А.; Вернадский Г. В.; Глезер А. Д.; Горбатов А. Н.; Гудзий Н. К.; Дерингер А. А.; Ефрон С. А.; Кнорринг И. Н.; Костелянец Б. О.; Лилиева Л. А.; Ляховицкий А. Б.; Миклашевский К. М.; Морозова О. Г.; «Нелли»; Никитина Е. Ф.; Офросимов Ю. В.; Перфильев А. М.; Плоткин Л. А.; Попов Л. А.; Рабинович А. Я.; Рафалович С. Л.; Тимофеевский А. А.; Толстой А. Н.; Фоогд- 
Стоянова Т. Ф.; Человек из угрозыска; Чулков Г. И.; Штейгер А. С.; Эткинд Е. Г.).

VI. Анна Ахматова: Эпоха, судьба, творчество: Крымский Ахматовский научный сборник. Вып. 4. Симферополь: Крымский Архив, 2006. С. 142-180 (Бажанов Б. В.; Вулф В.; Горенко И. А.; Гумилева А. И.; Евтушенко Е. А.; Журавлев В. А.; Иванова-Романова Н. М.; Ивашкевич Я; Ивич А. (Берштейн И. И.); Йонекава М.; Кузьмин А. В.; Линецкая Э. Л.; Недгар-Виленский Ю. М.; Нейман С. К.; Оттен Н. Д.; Посвянский П. Б.; Пресс Т. Н.; Рабинович (Раич) Е. И.; Рахел (Блувштейн Р.; Селиверстов И. В.; Тименчик Р. Д.; Томек В.; Тур Н. И.; Турганов Б. А; Тырса Н. А.; Цюй Юань; Шумаков Ю. Д.; Шуплецов Б. В.).

VII. На меже меж Голосом и Эхом: Сборник статей в честь Татьяны Владимировны Цивьян. М.: Новое издательство, 2007. С. 331-346 (Дидона; Лафорг Ж.; Нерваль Ж. де).

VIII. Анна Ахматова: Эпоха, судьба, творчество: Крымский Ахматовский научный сборник. Вып. 5. Симферополь: Крымский Архив, 2007. С. 156-189 (Головчинер Е. М.; Гольдштейн М. Э.; Квливидзе М. Г.; Клычков С. А.; Ландман М. Х.; Лансере Е. Е.; Лёвберг М. Е.; Левин Г. М.; Левин Ю. Д.; Левина Ю. И.; Левитин Е. С.; Либединская Л. Б.; Ли-Хунчанг; Майков А. Н.; Маршалл Г.; Садецкий А. А.; Сапаров М. А.; Стеллецкая К. К.; Чагин П. И.; Эвин Э. Э.; Юткевич С. И.; Якобсон Е. И.; Яровая В. (Кудрявцева В. Н.); Яхонтов В. Н.).

IX. Пути искусства: Символизм и европейская культура XX века. М.: Водолей Publishers, 2008. С. 391-471 (Антоновский Ю. М.; Бородаевский В. В.; Вертинский А. Н.; Гофман М. Л.; Гржебин 3. И.; Измайлов А. А.; Кривич В.; Кругликова Е. С.; Лодий 3. П.; Мар С. Г; Мочульский К. В.; Павлович Н. А.; Прокофьев С. С.; Редько А. М.; Розанов В. В.; Рубинштейн И. Л.; Тиме-Качалова Е. И.; Шелли Дж.; Ясинский И. И.).

Х. Анна Ахматова: Эпоха, судьба, творчество: Крымский Ахматовский научный сборник. Вып. 7: К 120-летию со дня рождения 
поэта. Симферополь: Крымский Архив, 2009. С. 37-82 (Айхенвальд Ю. И.; Аксенов И. А.; Баблер О.; Беляев Ю. Д.; Беньяш Р. М.; Браун Н. Л.; Герцык Е. К.; Дойл А.; Дони А.; Евсеева С. Г.; Заболоцкий Н. А.; Костин К. И.; Крейн А. З.; Марков К. К.; Рубенс П. П.; Рывина Е. И.; Рыкова Н. Я.; Скукалек Р.; Софинский В. Н.; Фелипе Л.; Фиш Г. С.; Форд Д.; Харин И. Н.; Целков О. Н.; Чен Дж.; Чудакова В. В.; Шадрин А. М.; Шамурин Е. И.; Шошин В. А.; Штаммлер Х.; Эрик Л. Н.; Юнгер В. А.).

XI. Memento vivere: Сборник памяти Л. Н. Ивановой. СПб.: Наука, 2009. С. 529-548 (Гитович С. С.; Кудрейко А. А.; Мегаев Г. Г.; Нейман Ю. М.; Одоевцева И.; Старокадомский К. Г.).

XII. Пермяковский сборник. Ч. 2. М.: Новое издательство, 2010. С. 561-617 (Багрицкий Э. Г.; Бану-Лахути Ц. Б.; Барашкова А. Ф.; Башинджагян Г. Х.; Башинджагян 3. Г.; Беляков М. М.; БогдановБерезовский В. М.; Бурже П.; Вертинский А. Н.; Вишневская Н. А.; Вырубова А. А.; Мегаев Г. Г.; Миклашевский К. М.; Миндлин Э. Л.; Мурин Б. Ю.; Нерис С.; Николай II; Нолле Н. А.; Пятин С. Г.; Ремизов А. М.; Руманов А. В.; Самарин Р. М.; Слётов П. В.; Сорин С. А.; Судейкин С. Ю.; Троцкий Л. Д.; Эльснер В. Ю.; Юткевич С. И.; Ярмуш М. Ю.).

XIII. Лесная школа: Труды VI Международной летней школы на Карельском перешейке по русской литературе. Поселок Поляны (Уусикирко) Ленинградской области: [б. и.], 2010. С. 143-172 (Апулей; Бордье Ж.-М.; Дорошинская Е. М.; Павлова К. К.; Познер В. С.; Полетаев Е. И.; Попов Г. Н.; Рогов В. В.; Сартр Ж.-П.; Слуцкий Б. А.; Чижевский Д. И.; Юркун Ю. И.; Яковлева Т. А.; Яшвили П.; Яшен К. Н.).

XIV. Анна Ахматова: Эпоха, судьба, творчество: Крымский Ахматовский научный сборник. Вып. 8. Симферополь: Крымский Архив, 2010. С. 34-71 (Бердслей О.; Бруни Н. А.; Гофман Э. Т. А.; Долинин-Искоз А. С.; Дончин Ж.; Казанова Дж.; Кондрашев Г. Ф.; Нейгауз Г. Г.; Никулин Л. В.; Парни Э.; Саломея; Форш О. Д.). 
XV. Блоковский сборник XVIII: Россия и Эстония в XX веке. Диалог культур. Тарту: Tartu Ülikooli Kirjastus, 2010. С. 26-51 (Городецкая А. А.; Городецкий С. М.).

XVI. Russica Romana. 2010. Vol. XVII. P. 203-222 (Вишневский В. В.; Илия; Козырев С. П.; Метро А.; Мурузи А. Д.; Павлова (Палей) М. Э.; Соловьев С. Ф.; Эйфель Ж.).

XVII. От Кибирова до Пушкина: Сборник в честь 60-летия Н. А. Богомолова. М.: Новое литературное обозрение, 2011. С. 599-621 (Амусин И. Д.; Антиной; Брюно Г.; Д’Аннунцио Г.; Исайя; Лавренев Б. А.; Орлов В. Н.; Павленко П. А.; Словеснов Н. А.; Эредиа Ж.).

XVIII. Некалендарный XX век. М.: Азбуковник, 2011. С. 408-445 (Бобров С. П.; Брандыс К.; Гофман В. В; Гоцци К.; Калиостро; Лансере Е. Е.; Огинская Л. Ю.; Фаммуз; Энценсбергер Г. М.).

XIX. Анна Ахматова: Эпоха, судьба, творчество: Крымский Ахматовский научный сборник. Вып. 9. Симферополь: Крымский Архив, 2011. С. 109-145 (Ахмадулина Б. А.; Цирель-Спринцсон С. Д.; Якубович Д. П.).

XX. Toronto Slavic Quarterly. 2012. № 40. C. 366-387 (Чуковский К.). XXI. Venok: Studia slavica Stefano Garzonio sexagenario oblata. In Honor of Stefano Garzonio / Ed. by Guido Carpi, Lazar Fleishman and Bianca Sulpasso. Stanford: Berkeley Slavic Specialties, 2012. P. 324-352 (Stanford Slavic Studies. Vol. 40) (Великий Немой; Каннегисер Л. А.; Козловский А. К.; Медный Всадник; Солсбери Г.; Чаплин Ч.).

XXII. Стих. Проза. Поэтика: Сборник статей в честь 60-летия Ю. Б. Орлицкого. New York: Ailuros Publishing, 2012. С. 532-543 (Бицилли П. М.; Квятковский А. П.; Малахов С. А.).

XXIII. История литературы. Поэтика. Кино. Сборник в честь Мариэтты Омаровны Чудаковой. М.: Новое издательство, 2012. С. 430-452 (Зелинский К. Л.).

XXIV. From Medieval Russian Culture to Modernism: Studies in Honor of Ronald Vroon. Frankfurt am Main: Peter Lang, 2012. C. 265-313 
(Буренин В. П.; Вечный жид; Голенищева-Кутузова О. В.; Добин Е. С.; Костелянец Б. О.; Летучий Голландец; Наполеон; Неведомский В. К.; Пастернак Е. Б.; Поливанова А. А.; Селиверстов И. В.; Старостин А. П.; Степанов Н. Л.; Шварсалон В. К.).

XXV. «...Как в прошедшем грядущее зреет...»: Полувековая парадигма поэтики серебряного века. М.: Азбуковник, 2012. С. 289-330 (Авраменко И. К; Аллилуева С. И.; Анненкова Е. Б.; Долматовский Е. А.; Дымшиц А. Л.; Лоретти Р.; Никитина 3. А.; Чеботаревская-Сологуб А. Н.; Шенгели Г. А.).

XXVI. Анна Ахматова: Эпоха, судьба, творчество: Крымский Ахматовский научный сборник. Вып. 10. Симферополь: Крымский Архив, 2012. С. 141-167 (Качанова-Лифшиц И. Н., Лифшиц В. А., Малышкин А. Г., Чулков Г. И., Юнгер Е. В.).

XXVII. Анна Ахматова: Эпоха, судьба, творчество: Крымский Ахматовский научный сборник. Вып. 11. Симферополь: Крымский Архив, 2013. С.143-161 (Катаев В. П., Качалов В. И., Козин С. А., Рагозина С. И., Сарьян М. С., Сахар (Лидарцева) Н. Я., Топорнин A. H.).

XXVIII. Анна Ахматова: Эпоха, судьба, творчество: Крымский Ахматовский научный сборник. Вып. 12. Симферополь: Крымский Архив, 2014. С.118-149 (А-това А., Арцыбашев М. П., Бенуа А. Н., Домогацкий Б. С., Евгеньев-Максимов В. Е., Ершов И. В., Иваск Ю. П., Корнфорд Ф. К., Ратгауз Г. И., Фор П., Яковлева Т. А.).

XXIX. Acta Slavica Estonica VII: Блоковский сборник XIX: Александр Блок и русская литература Серебряного века. Тарту: Tartu Ülikooli Kirjastus, 2015. С. 152-174 (Зенкевич М. А., Нарбут В. И.).

XXX. Литературная жизнь: Статьи. Публикации. Мемуары: Памяти А. Ю. Галушкина. М.: ИМЛИ РАН, 2017. С. 271-284 (Шкловский В. Б.).

XXXI. Wiener Slawistisches Jahrbuch. 2018. Vol. 6. S. 217-235 (Воложенинов И. К., Гатов А. Г., Гербер А. Е., Кощей Бессмертный, Малиа М., Наринская Р. Л., Овчаренко (Бондаренко) О. Т., Отеро 
Сильва М., Рахманов Ю. В., Слонимский М. Л., Струве Г. П., Тюханова Л А.).

XXXII. Across Borders: Essays in $20^{\text {th }}$ Century Russian Literature and Russian-Jewish Cultural Contacts. In Honor of Vladimir Khazan / Ed. by Lazar Fleishman and Fedor Poljakov. Berlin: Peter Lang, 2019. C. 31-47 (Stanford Slavic Studies. Vol. 48) (Аничков Е. В., Гуль Р. Б., ГумилеваФрейганг А. А., Марков В. Ф., Оболенская О. А., Сеземан Д. В.).

В ахматовском ономастиконе, так как он представлен в ее поздних рабочих блокнотах, рядоположены имена «врагов и друзей, друзей и врагов», - как сказано в одном ее позднем стихотворении, - живых и мертвых, знакомых и незнакомых, реальных лиц и литературных персонажей, всенепременных или занесенных случайно, ожидаемых или оставляющих зазор для недоумения. О последних - подробнее.

При том, что задачей, поставленной перед собой нашим комментарием в форме пространного и ветвящегося именного указателя является следование не столько принципу «кто есть кто?», сколько - «с какой стати?», «почему здесь?» или «что вдруг?» (см.: Тименчик 2006: 142; Тименчик 2008: 24-26, 583, 586; Тименчик 2010: 144), в ряде случаев мы все-таки вынуждены ограничиться неокончательными предположениями. Так, появление имени «Гедеонова» гипотетически объясняется прямым или косвенным запросом кого-то из кругов, близких или к редакции «Нового мира», или к И. Г. Эренбургу. Не уверены мы и в окончательности идентификации «Лосева». Когда в туринском издании ахматовских блокнотов «еще один царскосел» был определен как поэт «Лев Лосев», я предупредил последнего о случившемся недоразумении, предположив, что речь на самом деле может идти о погибшем в блокаду почтенном краеведе, и он отвечал 2 ноября 1997 г.: «...а ведь на этом можно было бы выстроить легенду, как я восхитил А. А. своими воспоминаниями и она объявила меня “еще одним царскоселом"! А Вы - какой-то краевед... Но на самом деле я не царскосел, а малодетскосел, потому что улица, на которую выходило мое окно с 1947 по 1963 г., называется Малодетскосельский проспект». 
Бонч-Бруевич Владимир Дмитриевич (1873-1955) - директор Государственного литературного музея (см.: Ахматова 1996: 270).

Помета к эпиграмме О. Э. Мандельштама, обыгравшей название трагедии В. Кюхельбекера, который писал: «Автор назвал свою трагедию “Аргивянами”, потому что хор в оной состоит из пленных аргивян» - жителей Аргоса, или Арголиды:

На берегу каких-то вод

Живут архивяне - народ

Довольно древний, - всем на диво

Паршивый промысел его

Начальству продавать архивы...

- «30-ые годы. Когда Бонч не купил арх<ива>» (Ахматова 1996: $270)$ - т. е. когда предложенные О. Мандельштамом документы были оценены весьма невысоко (см.: Флаттеров [Добкин] 1979: 432-437).

См. слухи, сопровождавшие его деятельность: «...В. Д. БончБруевич, бывший секретарь Ленина и управляющий делами Совнаркома. А перед войной - директор Государственного Литературного музея. Музей был его детище. Надо отдать справедливость: в короткий срок он проделал большую работу. $<\ldots>$ Накопил много материалов, относящихся к истории русской литературы и русской общественной мысли вообще. Только... делалось это какими-то откровенно-бандитскими методами. По всей стране шныряли “агенты Бонча". Достаточно было им пронюхать, что у какой-то старушки хранится “прабабушкин альбом”, как обладательница должна была проститься с вещью: приходили, просили “поглядеть” и забирали как предмет “государственной необходимости”» (Коряков 1947: 89-90); ср. также воспоминания его сотрудника: «Бонч-Бруевич был организатор с инициативой и практическим смыслом; из сопротивления он черпал новые силы для борьбы на пути к намеченной цели. С помощью своих связей, общественных и литературных, он умел открывать как в Москве, так и в провинции тайники, где лежали под спудом в частных руках нужные ему рукописные материалы, и не успокаивался до тех пор, пока они не делались собственностью музея, в большинстве случаев 
за бесценок. С каким мастерством вел Бонч-Бруевич переговоры с продавцами рукописей, в большинстве тогда нуждавшимися, указывает такой, например, случай. Некто К. при встрече со мной выразил негодование, что Ленинская библиотека оценила всего в 700 рублей обширный эпистолярный архив его деда с автографами ряда, правда, второстепенных деятелей журналистики. “Я предпочитаю, - заключил он, - ходить в рваных сапогах, нежели передать архив скифам и невеждам!" <...> встречаю К. на Моховой у станции метро. Сияет... Оказывается, ему, наконец, удалось устроить архив в надежные руки, где понимают его значение и ценность, - в Литературный музей. На вопрос - сколько же за него уплатили, последовал ответ - 600 рублей. В сходном положении оказывалось большинство продавших Бончу свои рукописи. Чему приписать здесь сговорчивость: красноречию Бонча или собственной вопиющей нужде - сказать, конечно, трудно.

Были, однако, лица, обвиняющие Бонч-Бруевича в скаредности и даже вымогательстве. А. И. Л. рассказывала мне лично, как она принесла Бончу две небольшие записки на французском языке неопубликованные автографы А. С. Пушкина. Бонч принял ее у себя в кабинете, долго и внимательно рассматривал записки через лупу, затем, молча положив их под стекло на письменном столе, предложил посетительнице получить в кассе музея 300 рублей и встал в знак того, что аудиенция закончена. Та остолбенела. Тогда Бонч пояснил ей хладнокровно, что подготовленным постановлением Совнаркома все автографы А. С. Пушкина объявлены национальной собственностью, поэтому за них нельзя уплатить ни гроша; что 300 рублей - не более как щедрое возмещение расходов по их доставке. Протесты и упреки ни к чему не привели, и Л. удалилась, унося с собою, взамен автографов, 300 рублей. Спустя 25 лет Л. вспоминала об этом с раздражением. Дело в том, что постановление Совнаркома, на которое ссылался Бонч, так и не было издано.

Следует, однако, отметить, что порицавшие Бонча за скупость держались своей связи с ним и в случае надобности с новыми предложениями рукописей обращались не в Ленинскую библиотеку, а к нему» (Ильин 1990: 290). 
В 1965 году в разговоре с Никитой Струве Ахматова вспоминала: «Все мы это так, перед грозой отдавали свои альбомы БончБруевичу, а он их скупал для государственного архива» (Ахматова 1968: 332). К Ахматовой В. Д. Бонч-Бруевич обратился 8 мая 1933 г.:

Многоуважаемая Анна Андреевна, Я только что сейчас получил Ваш адрес от [Д. П.] Якубовича и немедленно пишу Вам, чтобы просить Вас не отказать нам принять участие в наших сборниках «Звенья» Вашими прекрасными исследованиями по Пушкину. Если еще что надумаете, - пожалуйста, высылайте. Если у Вас есть что-либо готовое по Пушкину, то как раз я кончаю редактирование 5-й книги «Звеньев», 3-я печатается в Ленинграде, 4-я - в Москве. В 5-й том мы могли бы еще поместить Вашу статью, если она не очень запоздала бы. Кстати, позвольте познакомить Вас с нашим Центральным Литературным Музеем, которому теперь придано название: «Центральный Музей художественной литературы, критики и публицистики». Из общего установочного письма, которое мы при сем Вам посылаем, Вы увидите наши цели и задачи. Я был бы очень рад и благодарен Вам, если бы Вы сообщили мне, нет ли у Вас чего-либо из эпистолярной литературы, что бы Вы захотели к нам поместить? Тогда нужно было бы прислать опись всех этих материалов, наша Фондовая Комиссия их осмотрела бы и оценила, и мы у Вас все это приобрели бы ${ }^{1}$.

9 августа 1933 г. Ахматова писала Н. И. Харджиеву в Москву из Ленинграда: «Бонч предлагает мне продать мой архив. Напишите несколько слов хоть по почте!» (цит. по: Баран 1974: 8-9).

Следующее письмо В. Д. Бонч-Бруевича написано 11 января 1934 г.:

Многоуважаемая Анна Андреевна, когда Вы уезжали, Вы сказали мне, что в конце 1933 г. или начале 34 г. Вы пришлете нам новую партию материалов, которые Вы хотели предложить нашему Музею.

1 НИОР РГБ. Ф. 369. К. 126. Ед. хр. 57. 
Считаю своим долгом сообщить Вам, что наш корабль вновь оснащен солидными парусами и мы можем приобретать все новые и новые архивы и пускаемся в плавание в нынешнем году значительно более крепкими, чем в прошлом году. Мы намерены широким неводом вылавливать из нашей огромной страны все, что только касается вопросов художественной литературы, критики и публицистики, искусства, истории, быта. Я очень прошу Вас помочь нам в этом деле и прежде всего я жду не дождусь, когда Вы пришлете нам новую посылку из Вашего собственного архива.

Буду рад, если Вы о Ваших намерениях сообщите мне по адресу: Москва, 31, Рождественка 5, 1-й этаж, Центральный Музей художественной литературы, критики и публицистики.

Всего Вам наилучшего. Директор ЦМЛ Влад. Бонч-Бруевич².

См. протоколы заседаний фондовой комиссии от 15 февраля 1934 г.:

Слушали: Предложение А. А. Ахматовой приобрести материалы из ее архива. Оценка 3000 руб. Постановили: Материалы приобрести. Оценку владелицы считать чрезмерно преувеличенной. Передать малой комиссии на детальную оценку.

- и от 25 февраля 1934 г.:

Слушали: Предложение А. А. Ахматовой по оп. 1016 приобрести материалы из ее архива (экспертиза Н. С. Ашукина). Оценка владелицы 3000 руб. Постановили: Приобрести за 1200 руб. с передачей Музею авторского права3

Ср. в публичном оглашении: «Приобретены также материалы Ахматовой» ${ }^{4}$.

Судя по картотеке Государственного литературного музея (РГАЛИ), у разных лиц также были приобретены: список стихотворения «В комнате моей живет красивая...»- от И. С. Клей-

\footnotetext{
2 НИОР РГБ. Ф. 369. К. 126. Ед. хр. 57.

НИОР РГБ. Ф. 369. К. 105. Ед. хр. 7. Л. 214, 220; сообщено П. М. Нерлером.

4 Бруевич-Бонч В. Новые вклады в наше литературное наследство. - За коммунистическое просвещение. 1934. № 126 (125). 3 июня.
} 
нершехета-Соломина, автографы стихотворений - «Я окошка не завесила» - от журналиста Ю. Бочарова, «Земной отрадой сердца не томи» - от Ю. И. Юркуна, «Я с тобой не стану пить вино» (по-видимому, листок из альбома А. И. Тинякова; дата записи 26 января 1914 г.) - от журналиста С. М. Шпицера; машинопись «Путник милый! Ты далече» - от И. В. Грузинова и др. (см.: Евстигнеева 1989: 53-55).

Бунин Иван Алексеевич (1870-1953) - поэт, прозаик, лауреат Нобелевской премии (1933).

Назван в числе «уничтожавших стихи Ахматовой» (Ахматова 1996: 453) - имеется в виду стихотворение «Поэтесса» (3 января 1916 г.):

Большая муфта, бледная щека,

Прижатая к ней томно и любовно,

Углом колени, узкая рука...

Нервна, притворна и бескровна.

Все принца ждет, которого все нет,

Глядит с мольбою, горестно и смутно

«Пучков, прочтите новый триолет»

Скучна, беспола и распутна 5 .

Пучков - возможно, использовано реальное имя поэта Анатолия Ивановича Пучкова (1894-1973), книгу которого «Последняя четверть луны» Н. Гумилев оценивал в «Письмах о русской поэзии» в № 10 журнала «Аполлон» за 1915 г.; Георгий Адамович писал по поводу этого стихотворения: «Но ведь этой “смутной и горестной” поэтессой могла быть и Ахматова! Бунин, конечно, понимает это. Но ему нет дела до эстетики, он осуждает мир, которым живет “поэтесса": ее печаль, ее предчувствия, неисцелимую скуку, ее “выверт", как бы не видя всего того, что за этим вывертом стоит, - в плане историческом или общекультурном» ${ }^{6}$ в в 1940 г. Л. К. Чуковская

5 Впервые: Жизнь. Одесса. 1918. № 7. С. 1.

6 Адамович Г. Литературные беседы. - Звено. 1926. № 157. 31 января. 
записала: «Недавно ей показали строки Бунина, явно написанные про нее, хотя имя ее там не упомянуто. Она прочитала мне эти стихи наизусть. Там муфта, острые колени, принца ждет, беспутная, бесполая. Стихи вялые, бледные. Ее внешний образ составлен из альтмановского портрета и из "Почти доходит до бровей / Моя незавитая челка". Мне было стыдно подтвердить на ее спрос: да, это про вас. Стыдно за Бунина» (Чуковская 1997а: 114; цитируемое стихотворение «Дама в лиловом» опубликовано в «Северных записках» в 1914 году). Валентин Катаев в повести «Трава забвения» приводил принадлежащую Бунину, как будто, фразу: «Ахматова - провинциальная барышня, попавшая в столицу» (Катаев 1972: 293); о бунинском «полном равнодушии к Ахматовой» см.: Адамович 2001: 226.

Неприятие Буниным ахматовской поэтики недоговоренности, "ролевой лирики» и логических скачков зафиксированы в его замечаниях на полях ее текстов. На аукционе № 109 московского аукционного дома «Литфонд» 13 июня 2018 года выставлялся экземпляр «Подорожника» (Пг.: Petropolis, 1921) (одно время находившегося в собрании слависта Роберта Кембалла) с пометами Бунина ${ }^{7}$, некоторыми - весьма проницательными (о нарочитости текста акростиха «Борису Анрепу»), некоторыми - по-читательски наивными (шпоры принадлежали не Гумилеву, а тому же Анрепу), некоторыми - запрограммированными загадочностью текста (заглавие сборника было разъяснено Ахматовой двадцать лет спустя в стихотворении «Надпись на книге «Подорожник»):

На титульном листе:

«Почему Подорожник?»

На стр. 15:

Когда о горькой гибели моей

Весть поздняя его коснется слуха,

Не станет он ни строже, ни грустней,

\footnotetext{
7 См. описание лота (с фотографиями помет на обложке и на стр. 15, 21, 29,35 и 50): [http://www.litfund.ru/auction/102/271/].
} 
Но, побледневши, улыбнется сухо.

И сразу вспомнит зимний небосклон

И вдоль Невы несущуюся вьюгу,

И сразу вспомнит, как поклялся он

Беречь свою восточную подругу.

«Все кто-то “роковой”»<.>

Ha стр. 21:

По неделе ни слова ни с кем не скажу,

Все на камне у моря сижу,

И мне любо, что брызги зеленой волны,

Словно слезы мои, солоны.

Были весны и зимы, да что-то одна

Мне запомнилась только весна.

Стали ночи теплее, подтаивал снег,

Вышла я поглядеть на луну,

И спросил меня тихо чужой человек,

Между сосенок встретив одну:

«Ты не та ли, кого я повсюду ищу,

О которой с младенческих лет,

Как о милой сестре, веселюсь и грущу?»

Я чужому ответила: «Нет!»

А как свет поднебесный его озарил,

Я дала ему руки мои,

И он перстень таинственный мне подарил,

Чтоб меня уберечь от любви.

И назвал мне четыре приметы страны,

Где мы встретиться снова должны:

Море, круглая бухта, высокий маяк,

А всего непременней - полынь...

И как жизнь началась, пусть и кончится так.

Я сказала, что знаю: аминь! 
На стр. 22:

Ты всегда таинственный и новый,

Я тебе послушней с каждым днем,

Но любовь твоя, о друг суровый,

Испытание железом и огнем.

Запрещаешь петь и улыбаться,

А молиться запретил давно.

Только 6 мне с тобою не расстаться,

Остальное все равно!

Так, земле и небесам чужая,

Я живу и больше не пою,

Словно ты у ада и у рая

Отнял душу вольную мою.

«Замечательный!»

На стр. 23:

Проплывают льдины, звеня,

Небеса безнадежно бледны.

$\mathrm{Ax}$, за что ты караешь меня,

Я не знаю моей вины.

Если надо - меня убей,

Но не будь со мною суров.

От меня не хочешь детей

И не любишь моих стихов.

Все по-твоему будет: пусть!

Обету верна своему,

Отдала тебе жизнь, но грусть

Я в могилу с собой возьму.

«Да что случилось?» 
На стр. 24:

В каждых сутках есть такой

Смутный и тревожный час.

Громко говорю с тоской,

Не раскрывши сонных глаз.

И она стучит, как кровь,

Как дыхание тепла,

Как счастливая любовь,

Рассудительна и зла.

«Все загадочность!»

На стр. 25:

Земная слава как дым,

Не этого я просила.

Любовникам всем моим

Я счастье приносила.

Один и сейчас живой,

В свою подругу влюблённый,

И бронзовым стал другой

На площади оснежённой.

«Слава! Скучно, однообразно»<.>

Hа стр. 27:

О нет, я не тебя любила,

Палима сладостным огнем,

Так объясни, какая сила

В печальном имени твоем.

Передо мною на колени

Ты стал, как будто ждал венца,

И смертные коснулись тени

Спокойно юного лица.

И ты ушел. Не за победой,

За смертью. Ночи глубоки! 
О, ангел мой, не знай, не ведай

Моей теперешней тоски.

Но если белым солнцем рая

В лесу осветится тропа,

Но если птица полевая

Взлетит с колючего снопа,

Я знаю: это ты, убитый,

Мне хочешь рассказать о том,

И снова вижу холм изрытый

Над окровавленным Днестром.

Забуду дни любви и славы,

Забуду молодость мою,

Душа темна, пути лукавы,

Но образ твой, твой подвиг правый

До часа смерти сохраню.

«Опять!»

На стр. 29:

Я слышу иволги всегда печальный голос

И лета пышного приветствую ущерб,

А к колосу прижатый тесно колос

С змеиным свистом срезывает серп.

И стройных жниц короткие подолы,

Как флаги в праздник, по ветру летят.

Теперь бы звон бубенчиков веселых,

Сквозь пыльные ресницы долгий взгляд.

Не ласки жду я, не любовной лести

В предчувствии неотвратимой тьмы,

Но приходи взглянуть на рай, где вместе

Блаженны и невинны были мы.

«Глупый винегрет»<.> 
Отчеркнуты строки и поставлен знак вопроса:

Теперь бы звон бубенчиков весельх,

Сквозь пыльные ресницы долгий взгляд.

На стр. 30:

Как страшно изменилось тело, Как рот измученный поблек!

Я смерти такой не хотела,

Не этот назначила срок.

Казалось мне, что туча с тучей

Сшибется где-то в высоте

И молнии огонь летучий,

И голос радости могучей,

Как ангелы сойдут ко мне.

«Все то же!»

На стр 35:

От любви твоей загадочной,

Как от боли, в крик кричу,

Стала желтой и припадочной,

Еле ноги волочу.

Новых песен не насвистывай, -

Песней долго ль обмануть,

Но когти, когти неистовей

Мне чахоточную грудь,

Чтобы кровь из горла хлынула

Поскорее на постель,

Чтобы смерть из сердца вынула

Навсегда проклятый хмель.

«Мучительно-кошачья любовь!» 
На стр. 36:

Чем хуже этот век предшествующих? Разве

Тем, что в чаду печали и тревог

Он к самой черной прикоснулся язве,

Но исцелить ее не мог.

Еще на западе земное солнце светит

И кровли городов в его лучах блестят,

А здесь уж белая дома крестами метит

И кличет воронов, и вороны летят.

«Кто это?»

На стр. 38:

По твердому гребню сугроба

В твой белый, таинственный дом

Такие притихшие оба

В молчании нежном идем.

И слаще всех песен пропетых

Мне этот исполненный сон,

Качание веток задетых

И шпор твоих легоньких звон.

«Гумилев?»

На стр. 39:

Мурка, не ходи, там сыч

На подушке вышит,

Мурка серый, не мурлычь,

Дедушка услышит.

Няня, не горит свеча,

И скребутся мыши.

Я боюсь того сыча,

Для чего он вышит?

«Прикинулась девочкой!» 
На стр. 40:

Теперь прощай, столица,

Прощай, весна моя,

Уже по мне томится

Корельская земля.

Поля и огороды

Спокойно зелены,

Еще глубоки воды

И небеса бледны.

Болотная русалка,

Хозяйка этих мест,

Глядит, вздыхая жалко,

На колокольный крест.

А иволга, подруга

Моих безгрешных дней,

Вчера вернувшись с юга,

Кричит среди ветвей,

Что стыдно оставаться

До мая в городах,

В театре задыхаться,

Скучать на островах.

Но иволга не знает,

Русалке не понять,

Как сладко мне бывает

Его поцеловать!

И все-таки сегодня

На тихом склоне дня

Уйду. Страна Господня,

Прими к себе меня! 
На стр. 43:

Стоит на небе месяц, чуть живой,

Средь облаков струящихся и мелких,

И у дворца угрюмый часовой

Глядит, сердясь, на башенные стрелки.

Идет домой неверная жена,

Ее лицо задумчиво и строго,

А верную в тугих объятьях сна

Сжигает негасимая тревога.

Что мне до них? Семь дней тому назад,

Вздохнувши, я прости сказала миру,

Но душно там, и я пробралась в сад

Взглянуть на звезды и потрогать лиру.

«В огороде бузина, а в Киеве дядька.

Глуповато, наивно»<.>

На стр. 46:

Бывало, я с утра молчу,

О том, что сон мне пел.

Румяной розе и лучу,

И мне - один удел.

С покатых гор ползут снега,

А я белей, чем снег,

Но сладко снятся берега

Разливных мутных рек,

Еловой рощи свежий шум

Покойнее рассветных дум.

«Набор слов - как почти всюду»<.>

На стр. 47 :

И целый день, своих пугаясь стонов,

В тоске смертельной мечется толпа,

А за рекой на траурных знаменах

Зловещие смеются черепа. 
Вот для чего я пела и мечтала,

Мне сердце разорвали пополам,

Как после залпа сразу тихо стало,

Смерть выслала дозорных по дворам.

«Беспомощно»<.>

На стр. 50:

Проводила друга до передней,

Постояла в золотой пыли,

С колоколенки соседней

Звуки важные текли.

Брошена! Придуманное слово -

Разве я цветок или письмо?

А глаза глядят уже сурово

В потемневшее трюмо.

- слева от слова «Брошена!»: «Опять!⿱亠䒑.

Ср. в свою очередь отзыв Ахматовой о Бунине: «Вялые стихи, обо всем на свете, рассчитанные на академическую благовоспитанную публику. Сокровищ в них не ищите - как у Случевского или у Полонского или у Анненского. <... Поэты 90-х годов погибали от безвкусицы эпохи, не в силах были ее побороть, а Бунин был вполне удовлетворен своей эпохой. Когда при нем появился Блок, повеял новый ветер, он надел наушники, напульсники, набрюшники, думая, что так и должен вести себя классик. Очень глупая позиция» (цит. по: Чуковская 1997a: 364). Подробнее об отношении Ахматовой к Бунину см.: Тименчик 2014, 1: 384-385; Тименчик 2014, 2: 499-500.

8 декабря 1957 г. литературовед Ю. М. Калмыков из Саратова просил Ахматову поделиться «своим мнением о поэзии Бунина, тем, как в свое время относились к Бунину близкие Вам поэты»', но близкие Ахматовой поэты относились к поэзии Бунина равнодушно; см., например, свидетельство В. А. Зоргенфрея: «Блок целиком отвергал Гумилева. Гумилев целиком отвергал Бунина»

8 ОР РНБ. Ф. 1073. № 1361. 
(цит. по: Шелаева 1996: 260); ср.: «Символическое искусство будет главенствовать до тех пор, пока не устоится современное брожение мысли или - наоборот - не усилится настолько, чтобы его можно было гармонизировать поэтически. Вот почему стихи Бунина, как и других эпигонов натурализма, надо считать подделками, прежде всего - потому, что они скучны, не гипнотизируют. В них все понятно и ничего не прекрасно. Читая стихи Бунина, кажется, что читаешь прозу. Удачные детали пейзажей не связаны между собой лирическим подъемом. Мысли скупы и редко идут дальше простого трюка. В стихе и в русском языке попадаются крупные изъяны. Если же попробовать восстановить духовный облик Бунина по его стихам, то картина получится еще печальнее: нежелание или неспособность углубиться в себя, мечтательность, бескрылая при отсутствии фантазии, наблюдательность без увлечения наблюдаемым и отсутствие темперамента, который единственно делает человека поэтом» (Гумилев 1990: 112); ср. также уклончивую характеристику у И. Анненского: «Я не буду говорить о жанре и пейзаже у Бунина. Кто не знает его превосходного "Листопада", в свое время отмеченного и высоко авторитетной критикой? Но, по-моему, поэзия лауреата даже непонятна без анализа его часто отличной прозы. Да, пожалуй что Бунин уж и перерос свою ритмическую лирику» (Анненский 1979: 369). Ср. характерный эпизод: «Однажды я при Мандельштаме произнес начало последней строфы стихотворения Бунина “Имру-уль-Кайс":

Ночь тишиной и мраком истомила.

Когда конец?

Ночь, как верблюд, легла и отдалила

От головы крестец.

О. Э. почти шепотом сказал: “Как хорошо. Чье это?” Я назвал автора. На лице О. Э. появилось выражение, точно он проглотил что-то невкусное. Затем наступила небольшая пауза, после которой он начал: “Сразу можно определить слабого поэта. Вот у него...” и т. д.» (Кузин 1999: 170). 
Бунин помянул Ахматову в своих воспоминаниях, рассказывая с чужих слов о «Бродячей собаке»: «Богохульство, кощунство, одно из главных свойств революционных времен, началось еще с самыми первыми дуновениями “ветра из пустыни”. <...> В петербургской “Бродячей Собаке”, где Ахматова сказала: “Все мы грешницы тут, все блудницы”, поставлено было однажды “Бегство Богоматери с Младенцем в Египет”, некое “литургическое действо”, для которого Кузмин написал слова, Сац сочинил музыку, а Судейкин придумал декорацию, костюмы - “действо”, в котором поэт Потемкин изображал осла, шел, согнувшись под прямым углом, опираясь на два костыля и нес на своей спине супругу Судейкина в роли Богоматери. И в этой “Собаке” сидело не мало и будущих “большевиков”: Алексей Толстой, тогда еще молодой, крупный, мордастый, являлся туда важным барином, помещиком, в енотовой шубе, в бобровой шапке или в цилиндре, стриженый а ла мужик; Блок приходил с каменным, непроницаемым лицом красавца и поэта; Маяковский в желтой кофте, с глазами сплошь темными, нагло и мрачно вызывающими, со сжатыми, извилистыми, жабьими губами... Тут надо кстати сказать, что умер Кузмин - уже при большевиках, - будто бы так: с Евангелием в одной руке и с “Декамероном” Бокаччио в другой» (Бунин 1950: 45-46; ветер из пустыни - из стихотворения Блока «Из хрустального тумана...»; все мы грешницы тут - вместо: «все мы бражники здесь»; Бегство Богоматери - речь идет о представлении «Рождество Христа. Вертеп кукольный» 6 января 1913 г.; автором музыки был сам М. Кузмин; ср. впечатления С. А. Ауслендера: «...когда Мадонна вышла из вертепа и села на осла, казалось, что настоящая мистерия, настоящее тайное действо совершается под низкими сводами подвала» (Ауслендер 1913: 66); Блок - скорее всего в «Бродячей собаке» не бывал).

По этой теме см.: Двинятина 2001: 518-543. Ср. также статью, в которой приводится много словесных совпадений между бунинскими и ахматовскими текстами, а также на основании краткости фонологического расстояния И. А. Бунину переадресовывается стихотворение, посвященное Н. Н. Пунину, а также высказываются 
предположения о том, что было бы, если бы эти два поэта поженились, и много чего другого: Кралин 2002: 258-282.

Гедеонова Надежда Дмитриевна (1898-1973) - доцент по кафедре французского языка пединститута им. А. Герцена.

«(Гедеонова спросить у Тани Казанск<ой>)» (Ахматова 1996: 653). Дворянка по происхождению (брат офицер сослан в 1930 году на Соловки), смолянка, она была автором письма А. Т. Твардовскому от 20 ноября 1961 г. по поводу воспоминаний И. Эренбурга «Люди, годы, жизнь». Письмо носило недвусмысленный антисемитский характер (см.: Фрезинский 2013: 366-368). Татьяна Борисовна Казанская (1916-1989) - поэтесса, художница, переводчица, филолог - специалист по романским языкам, преподаватель пединститута им. А. Герцена.

Горенко (в замужестве - Гумилева) Анна Андреевна (1889-1966) будущая Ахматова.

«О<цуп >. Упоминание в поэме. (Несколько раз и даже гениальная Горенко)» (Ахматова 1996: 116); «Оц<уп> <...> (Анна Горенко)» (Ахматова 1996: 225). Имеется в виду перечисление царскосельских поэтов (И. Анненский, Н. Гумилев, В. Комаровский, Д. Коковцев, А. Ахматова) в автобиографической поэме Н. А. Оцупа «Дневник в стихах. 1935-1950» (Париж, 1950):

Анненский второй наперсник той

Музы, Царскосельской, а питомник:

Автор «Гондлы», ранящий порой

Чем-то Лермонтовским, наш паломник

«Дальних странствий», мастер, чей жираф

Испугал и восхитил торговцев

Книгами, и Комаровский граф,

Эллин, или Митенька Коковцев,

Мистик, или гениальная

Анна Горенко... ну и семья!

(Оцуп 1993: 268) 
«На “Жемчугах" [Н. С. Гумилев] написал мне: "Кесарю - Кесарево. Анне Горенко”» (Ахматова 1996: 289).

В год сорокалетия Ахматовой в сатирическом журнале в неподписанной подборке «Рычи - читай» (обыгрывающей название популярной тогда пьесы Сергея Третьякова «Рычи, Китай!») была помещена заметка «Ни БСЭ, ни ЛЭ» (не очень ловкий каламбур на тему выражения «ни бе, ни ме» - о непонимающих):

В томе IV (стр. 162) «Большой Советской Энциклопедии» напечатано:

«Ахматова - (псевдоним). Анна Андреевна Горленко (р. 1895 г.), выдающаяся поэтесса».

А в «Литературной Энциклопедии» (том I, стр. 280) находим: «Ахматова Анна (1888) Анна Андреевна Горенко, поэтесса».

Таким образом, по БСЭ Ахматова родилась в 1895 г., а по ЛЭ - в 1888 , по БСЭ - фамилия поэтессы - Горленко, а по ЛЭ - Горенко.

Анна Ахматова по этому поводу могла бы сказать:

Ax, как грустно! Как странно!

Мое сердце - корабль, затертый средь льдин.

По БСЭ - я Горленко Анна

И мне уже $41 \ldots$

Горенко? Горленко? За правдой не угнаться.

Врут календари и энциклопедии все!

Прочь, фарисеи! Мне - 18,

И не право ни ЛЭ, ни БСЭ!.. ([Б.п.] 1929: 11)

Ср. в автобиографическом наброске Ахматовой: «...все считают меня украинкой. Во-первых, оттого, что фамилия моего отца Горенко, во-вторых оттого, что я родилась в Одессе...» (цит. по: Мандрыкина 1979: 200). Ср. о послевоенных лагерях перемещенных лиц: «В распространяемых в этих лагерях украинских газетах совершенно серьезно говорится о том, что Зощенко и Ахматова преследовались потому, что они украинцы - Зощенко уроженец Полтавщины, а настоящая фамилия Ахматовой - Горенко. Доказывается также, что раздвоение души Чайковского происходило потому, что одна половина его души, светлая, то украинская половина, а другая, черная и 
мрачная, это, конечно, кацапская. Думаю, что Чайковский, Зощенко и Ахматова были бы чрезвычайно удивлены этими открытиями»" (Гуль 1950: 35). Ср. разговор с Ахматовой за неделю до ее смерти: "Аннна Андреевна, вышел Франко на русском языке, есть там стихи в Вашем переводе. Это как же, Вы с подстрочника переводили?”. На лице Ахматовой - благородное негодование: "Милая моя, вы, кажется, забыли, что моя фамилия - Горенко!” (Кочур 1997: 371).

По утверждению Ирины Одоевцевой Гумилев говорил ей: «Я шутя советовал ей подписываться не Ахматова, а Анна Горенко. Горе - лучше не придумать» (Одоевцева 1988: 299). Рассуждения о «жизнетворческой фатальности» имени Горенко в поэтическом универсуме Ахматовой см.: Мароши 2000: 9.

Крученых Алексей Елисеевич (1886-1968) - поэт.

Запись: «Круч<еных>. 21 февр<аля>. (tél<égramme>)» (Ахматова 1996: 95) - ср. дневник конфидентки Крученых от 26 февраля 1961 г. о поздравлениях ко дню рождения пожилого футуриста: «А. Е. получил поздравительное письмо из архива с тридцатью подписями, телеграмму от Ахматовой, хвалебное письмо от литературоведа Н. Берковского, написавшего, что в “Пощечине" футуристы признали Пушкина современником» (Сетницкая 1990: 185); копия телеграммы рукой А. Е. Крученых: «Дорогой Алексей Елисеевич. Поздравляю славным 75летием помнящая ваш бурный рассвет Ахматова ${ }^{10}$.

«Масленица $<\ldots>$ последняя пятница $<\ldots>$ в 3 ч. - у Либединск<ой> (Круч<еных>)» (Ахматова 1996: 304) - запись относится к посещению квартиры Л. Б. Либединской 22 февраля 1963 г., когда там отмечался день рождения А. Е. Крученых (см.: Либединская 2000: 36-37).

Впервые Ахматова увидела его в 1912 году: «В декабре АА с Николаем Степановичем была на выступлении футуристов (Бурлюк,

\footnotetext{
9 Гуль Р. Советские люди в Европе. - Народная правда. Париж. 1950. № 9-10.

10 РГАЛИ. Ф. 1334. Оп. 1. Ед. хр. 1081. Л. 119; автоцитата из стихотворения «Маяковский в 1913 году».
} 
Маяковский, Е. Гуро, Крученых)» (Лукницкий 1997: 29). Они вместе выступали на «Вечере о новом слове» в Тенишевском училище 8 февраля 1914 года. В крученыховской сдвигологии использовалась с обсценными ассоциациями строка из мадригала Сергея Рафаловича к Ахматовой (1916):

Кто угадает, что значит сия загадочная строка:

сплетяху лу сосанною

Оказывается, это посвящение Ахматовой поэта С. Рафаловича и напечатано оно так: сплетя хулу с осанною, а читается, как выше приведено - какой-то церковнослав. глагол или сплетяха, лу (сокращ. от Лулу?) - сосанна (имя или название от сосать?). Человеку, услыхавшему эту строку в первый раз от чтеца, наверно послышится такая странность. Это - пример звукового сдвига. $<\ldots>$ Сплетяху и сосанна - явления сдвига, лу - явление слома (обломок) <..> А вот монахиня Ахматова... но пощадим ее женскую стыдливость... (Крученых 1922: 5, 9).

Апеллируя к скабрезным сдвигам Крученых поры их соседствования в литературном Тифлисе 1918-1919 гг., Сергей Городецкий надписал ему на какой-то книжке в дни триумфального шествия ждановского постановления:

Суассанному Крученыху

Шлю поздраву братскую

Он мною не учен уху

Есть ахматскую ${ }^{11}$.

В начале 1920-х годов Крученых несколько раз высказывает свое недовольство Ахматовой. По поводу отзыва И. Эренбурга о «Подорожнике» в статье «Русская поэзия» (подписанной якобы французом Жаном Сало, Jean Salot; т. е. «неряхой» - «salaud») - «Стихи Ахматовой тоже молодят меня. Они не лучше и не хуже прежних это нечто раз данное, ровное и неизбывное. Я только страшусь тех

11 РГАЛИ. Ф. 1334. Оп. 1. Ед. хр. 146. Л. 3. 
минут, когда от классической “Белой стаи” она поворачивается к легкой внешней народности» (Эренбург 1922: 9) - Крученых в письме от 10 августа 1922 г. заметил: “Вещь” знаю - она отдыхает на Ахматовой» (Крученых 1990: 139); «Как ни дуются наши барышни и их кавалеры - все ж в России поэтес <sic!> нет. Правда, по “честному заверению" Чуковского, над одной замахала было тень Пушкина, - но как-то криво: другой «честный страж пушкинского мундира» - Брюсов - уверяет, что этой поэтесе лучше было бы не родиться (т.е. не печататься)! - всем ясно, что речь идет об Ахматкиной, которую расчистил Маяковский, обозвав ее “вовсе не поэтесой, а романсисткой”» (Крученых 1923: s. р.; Крученых 1992: 29); «Шапир[ш]тейном в футуристы зачислены Есенин, Мариенгоф и... Клюев! Жаль, что за бортом остались Вербицкая и Ахматова. Надеемся, что в следующем “исследовании” Шапирштейн исправит свою ошибку!!!» (Крученых 1992: 36; речь о книге: Шапирштейн-Лерс Я. Е. [Я. Эльсберг] Общественный смысл русского литературного футуризма (Нео-народничество русской литературы XX века). М.: Изд. А. Г. Миронова, 1922). Вероятно, к 1920-м годам относятся выписки к его недописанной статье «Два гроба - Гумилев и Ахматова» (РГАЛИ. Ф. 1334. Оп. 1. Ед. хр. 43).

Сразу после смерти Маяковского Крученых опубликовал свои записи его высказываний, в том числе: «(О книжке стихов А. Ахматовой 'Anno Domini' очень маленького формата): Ну и книжки пошли - под ноготь забьются! не найдешь!»; «Маяковский на трибуне. 1921-1924 гг. Ахматова - романсистка, Борисов в юбке. Стихи "На смерть Блока" сами напрашиваются, чтобы их так спеть (Напевает на мотив “Ухарь-купец” строчки Ахматовой: Слава тебе, нестерпимая боль, умер вчера сероглазый король)» (Крученых 1930a: 11, 3; Борисов (Гурович) Борис Самойлович (1873-1939) исполнитель цыганских романсов). Ср. газетный отклик: «Вряд ли наша мемуарная литература, особенно литература последних лет, знает другой образец такой самодовольной пошлятины, как два первых (и, надеемся, последних) выпуска “Разговоров Маяковского”, только что выпущенных А. Кручёных. Лицемерно взывая к “будущим исследователям", для которых он хочет сохранить облик 
“живого Маяковского на трибуне и в быту”, Кручёных в своих новых книжках спекулирует на подленьком интересе обывателя к слабостям больших людей. <..> И Кручёных с подлинно смердяковским сладострастием подбирает и “сценографически" (как он заверяет) записывает все то, что может прийти на язык человеку в его случайных, интимных и частных отношениях с людьми. <...> Если Маяковский когда-нибудь сболтнул: “Я имею дело с девушками от 16 лет до 60 ти, расстоянием не стесняюсь...”, то Смердяков считает необходимым довести об этом до сведения “будущих исследователей”. Если Маяковский скажет про свою возлюбленную: “Моя Лиля - лилипут. Моя Лиля весит пуд...", то Кручёных считает, что и эта антропометрическая деталь должна быть сохранена для потомства. А потом, как же это Смердяков может пройти мимо такого, например, диалога: “Маня: Я девушка... Маяковский: Приятно познакомиться... Отчего же вы не в музее? Таких уже давно в музей отдали. Странно, что вы на свободе ходите”... Может быть, Маяковский и мог что-либо подобное сказать. В Маяковском до последних лет сохранилось многое от старой дореволюционной богемы. <...> Кстати, личные комментарии Кручёных к “Разговорам Маяковского" поражают своим невежеством. Достаточно сказать, что известное стихотворение Анны Ахматовой:

Слава тебе, безысходная боль,

Умер вчера сероглазый король и т. д.

“биограф” Маяковского называет стихами... “на смерть Блока". Стихотворение это, как известно, написано Ахматовой в... 19091911 гг. и вошло в ее первый сборник “Вечер” (1911 г.). Мы не боимся сделать "рекламу” этой пошлятине: издание отпечатано типографским способом в количестве 300 экземпляров и разошлось. И хочется думать, что продолжения этого “издания” не последует» ${ }^{12}$. Крученых возражал:

12 Кут А. [А. Кутузов]. Маяковский с точки зрения Смердякова. - Вечерняя Москва. 1930. 7 июля. 
Названо "На смерть Блока" не мною, как то навязывает рецензент (см. Вечерняя Москва 7 июля 1930 г.), а самим Маяковским (что более чем очевидно для каждого, прочитавшего первый выпуск). Другой вопрос - зачем это сделал Маяковский?

Небезызвестно, что Анна Ахматова, еще в 1909-11 г. публично называла Блока «сероглазым королем», но наступило время и этот король для нее (поэтессы) умер. И вот в цикле стихов, посвященных Блоку, появилось, хотя и без названия «На смерть Блока» - как друга, как поэта - задолго до его физической смерти. Возможно, что это ходячее представление о стихах Ахматовой (м<ожет> б<ыть> легендарное) и послужило поводом для слов Маяковского. Во всяком случае аналогичный факт известен в биографии того же Блока: в стихах Марины Цветаевой «к Блоку» (изд. 1922 г.) имеется датированное 1916 г. и посвященное смерти этого поэта:

Думали - человек!

И умереть заставили.

Умер теперь - навек

Плачьте о мертвом ангеле («Стихи к Блоку»).

Та же возвышенная мистификация!.. (Крученых 1930b: 3; поправляем по допечатной версии: РГАЛИ. Ф. 1334. Оп. 1. Ед. хр. 691. Л. 13-14 об).

В его архиве сохранился черновик, возможно, неотправленного письма к Ахматовой:

[Уважаемая] Многоуважаемая Анна Андреевна, мною были записаны разговоры Маяковского, причем он определенно указывал, что стихи Ваши «Слава тебе безысходная боль» посвящены Блоку.

Несоответствие в хронологии: стихи [помечены] изданы в 1912 г., а в историю литературы Ваше знакомство с Блоком [относится] вошло как состоявшееся в 1919 г. (?) Однако Маяковский утверждал, что Вы называли Блока публично «сероглазым королем» еще в 1910. 
«Разговоры Маяковского» напечатаны <?> и лучшее [Маяковского] его было известно его друзьям. В свое время я не занимался специально этим вопросом, веря Маяковскому на слово.

Чтобы разъяснить недоумения в этом отношении для историков литературы я [просил бы] прошу Вас написать - к Блоку ли относится это стих<отворение> или к другому лицу.

А если возможно, то сообщить краткую историю создания Вашего [стихотворения] произведения, что конечно представит большой интерес для исследователей -

\section{Уважающий $\mathrm{Bac}^{13}$.}

В 1940 г. он написал стихотворение «Анне Ахматовой»:

Хлебнув смолы и жупела с самого дна, Вы уже не та светская дама,

Что были в тринадцатом году,

Вам не страшны никакая полынь и яма, Пожар, резак и игра в аду.

(Впервые: Пушкин 1990: 518)

«Игра в аду»- совместная поэма Крученых и Хлебникова в 1913 году; резак - неологизм Хлебникова, чья фамилия анаграммирована в открывающем стихе (Перцова 1995: 305-306) - см. в его «Песне мирязя»: «И, читая резьмо лешего, прочли: сила - видеть Бога без закопченого стекла, ваше сердце - железо копья. И резак заглядывал тонким звериным лицом через плечо. <...> Резьмодей же побег за берестой содеять новое тисьмо» (Хлебников 1930: 15); обращение Хлебникова к Ахматовой как к светской даме 1913 года под названием «Песнь смущенного» появилось в вышедшем в свет летом 1940 года томе: Хлебников 1940: 157.

Тогда же Ахматова познакомилась с «доделками» Крученых (впервые обнародованы в кн.: Крученых 1999), в 1942 году посланных им Пастернаку:

13 РГАЛИ. Ф. 1334. Оп. 1. Ед. хр. 691. Л. 16. 
Память теперь многое разворачивает...

Борис, ты видел:

летом, у тебя на даче,

в Переделкино,

Анна Андреевна Ахматова

улыбаясь,

приветствовала

мои к «Шестикнижию»

доделки.

Вспомни и ты, Борис,

и улыбнись.

I

Когда человек умирает,

изменяются его портреты.

По-другому глаза глядят, и губы

ульбаются другой ульбкой.

Я заметила это, вернувшись

$C$ похорон одного поэта.

И с тех пор проверяла часто,

имоя догадка подтвердилась.

А сказать вернее -

это вырастает

наша любовь к нему,

к ушедшему.

Сметается пыль будней,

омытый смертью

встает он, великий,

и переросший все портреты.

II

По мне<,> в стихах все должно быть некстати,

Не так, как у застегнутых людей. 
Муза

Когда я ночью жду ее прихода,

Жизнь, кажется, висит на волоске.

Что почести, что юность, что свобода

Пред милой гостьей с дудочкой в руке.

И вот вошла. Откинув покрывало,

Внимательно взглянула на меня.

Ей говорю: «Ть ль Данту диктовала

Страницы Ада?» Отвечает: «Я».

Лихие казни, чад, смола и жупел -

Всегда мое любимое оружье.

То знали: Маяковский, Велимир,

Кромешный Гоголь, Гамлет, Пушкин.

Вхожу к любимцу легкою походкой,

Но жизнь его дрожит на тетиве -

Пощады нет: чума, костер, сиротство,

Узнает все, до дна, в короткий век.

В подвалах памяти дотла сгною,

Коль соскользнет на мягкую стезю.

В историю войдет как червь худой,

И прозвище его сравнится с язвой и хурдой.

(Крученых 1999: 287-288)

«Шестикнижие» - сборник Ахматовой «Из шести книг».

По поводу этих вариаций Пастернак писал ему 15 февраля 1943 г.: «Я не знаю, не истолковала бы Анна Андреевна ложно некоторую общую твою необычность. Как бы она не показалась ей, в особенности при огорчительности ее жизни, легкостью и неуважением к ней, которых у тебя, конечно, нет и в помине» (Пастернак 2005: 339).

В 1942 году Крученых «доделал» напечатанное в «Красной нови» стихотворение «Наступление»: 
Речетворке вещунье

«Славно начато славное дело»

Анна Ахматова, «Наступление»

Приказ Ахматовой -

врага изматывай,

чтоб днем и ночью

его кровоточило,

чтоб сила его -

на смарку,

ему могилой

его хибарка.

Чтоб поскорее

сыграл он в ящик,

рухнул на стружки

из дел пропащих.

От Киева до Берлина

дрожат посинелые спины -

сплошная медвежья болезнь,-

к нам больше в Москву

не лезь!..

Приказ Ахматовой -

врага охватывай

и с флангов, и с тыла,

от Буга до Берлина.

Не помогут ему

шайки гадюк,

всюду давит его

задыха-кандрюк.

(Крученых 2002: s. p.; РГАЛИ. Ф. 2577 (Л. Брик).

Оп. 1. Ед. хр. 1515. Л. 22)

Кандрюк - видимо, производное от кондрашки.

Вероятно, Н. И. Харджиев переслал это стихотворение Ахматовой в Ташкент, на что она откликнулась 6 апреля 1943 г. «Передайте мой привет и благодарность Крученыху» и 2 июня 1943 г.: «Что Москва? Что Брики? Что додельщик Крученых?» (Баран 1974: 
12, 13). К Харджиеву Крученых обращался в стихотворении того же года («Московские встречи. Сентябрь 1943»):

$$
\begin{aligned}
& \text { Сердца - созвучьями, } \\
& \text { утрянною свирелью связаны } \\
& \text { лихой дударь Филонова } \\
& \text { и друг Ахматовой } \\
& \text { Вы - чуткость дегустатора } \\
& \text { Густейших строк }{ }^{14} \text {. }
\end{aligned}
$$

К московской поездке Ахматовой 1946 года относится ее дарственная надпись на фотографии 1922 года: «Алексею Крученых на память о молодой Ахматовой 9 апреля 1946» (Черных 2016: 483; РГАЛИ. Ф. 13. Оп.1. Ед. хр. 200. Л. 3). К этому же времени относится хранившийся в архиве Б. Л. Пастернака, как сообщал нам покойный Вадим Козовой, список двух стихотворений «из цикла "Пять стихотворений”» с пометой Крученых на стихотворении «И <sic!> дышали мы сонными маками...»: «В наше время так писать стыдно, Анна Андреевна».

К 13 июня 1955 г. относится приписка Ахматовой к дарственной надписи Пастернака Крученых на фотографии Ахматовой и Пастернака работы В. Славинского, сделанной 2 апреля 1946 г.: «Вагонмикст, взамен увезенного, дорогому Алеше. 20 апр. 1948. Б. П.»; «И я. Ахм. 13 июня 1955. Москва» (Черных 2016: 582; РГАЛИ. Ф. 13. Оп. 1. Ед. хр. 207) и в тот же день сделана дарственная надпись на книге с переводами Ахматовой: Цюй Юань. Стихи (М.: ГИХЛ, 1954): «А. К. от Ахм. В Москве» (Библиотека РГАЛИ). 28 июня 1955 года ему надписана «У самого моря» (Пб.: Алконост, 1921): «Ал. Крученых от автора с приветом» (Черных 2016: 583; РГАЛИ. Ф. 13. Оп. 4. Ед. хр. 3). В тот же день «она купила у Крученыха и сама привезла мне "Белую стаю”!» (Чуковская 1997b: 145-146). 29 февраля 1956 г. ему снова была надписана книга Цюй Юаня: «Алексею Крученых от современницы» (Черных 2016: 594; Библиотека РГАЛИ), 8 апреля 1956 г. - «Корейская классическая поэзия. Перевод Анны Ахматовой» (М.: ГИХЛ, 1956):

14 РГАЛИ. Ф. 2577. Оп. 1. Ед. хр. 1515. Л. 10. 
«А. Е. Крученых привет от А. А. А.» (Черных 2016: 597; Библиотека РГАЛИ).

Ахматовская запись 1957 года в одном из его альбомов: «Алексей Крученых! Поздравляю! Полвека литературной работы!» (Королева 1978: 297). Ср.: «В последние годы он стал многое оценивать поиному. Так, очень гордился тем, что Анна Андреевна Ахматова получила премию Петрарки. Думаю, в признании таланта Анны Ахматовой Алексей Елисеевич видел нечто большее - может быть, признание той грандиозной эпохи, к которой принадлежал сам...» (Тутова-Сенькина 1994: 140; речь идет о премии «Этна-Таормина» в декабре 1964 г.).

Об официальной репутации «голяка и бедняка», как называл его В. Шкловский (см.: Дувакин, Радзишевский 2017: 69), см.: «До Прокофьева у нас был первым секретарем Кочетов. <...> Сталинист, догматик. <...> "Писать надо по-простому, - учил он меня, - для народа, для людей, вот как я пишу. Вот я пишу про рабочий класс. “Журбины” роман, и все понятно, все ясно. Я помогаю и партии, и правительству, а то, что эта интеллигенция все мудрит, изощряется, кому это нужно, этот Серебряный век, все эти КрученыхПерекрученых, на хрена они нужны?"» (Гранин 2010: 113). На его кремации Борис Слуцкий прочитал «Когда погребают эпоху...» (см.: Александров 2002: 59; «...прочитал не самое лояльное по тем временам...»).

Кутасова Ольга Дмитриевна (1929-2013) - переводчица с сербохорватского и болгарского языков. Познакомилась с Ахматовой в 1957 г., когда готовила сборник переводов Й. Йовановича-Змая в Гослитиздате.

В списке адресатов дарения «Реквиема» в декабре 1962 г. - январе 1963 г. (см.: Ахматова 1996: 271). Записан номер ее телефона (см.: Ахматова 1996: 324). В списке приветов в Москву: «Нике [Глен], Юле [Живовой], Оле» (Ахматова 1996: 321). В списке подарков на Новый 1965 год (см.: Ахматова 1996: 593). Инскрипт на «Беге времени» (М.; Л.: Советский писатель, 1965): «Милой Оле Кутасовой - на счастие - Анна Ахматова 1 февраля 1966. Москва» (Ахматова 1996: 
693); в письме к нам от 5 июня 1998 г. она писала: «Значительность и теплоту надписи объясняю тем, что Анна Андреевна знала от моего ближайшего друга Ники, что незадолго до этого времени у меня родился сын...».

О ней см. в воспоминаниях Н. Н. Глен: «И вдруг: “По-моему, Оля (О. Кутасова, близкая моя подруга и в то время тоже гослитовский редактор) меня боится, потому что не может быть, чтобы она случайно так долго не приходила. Скажите ей, что я так же дружна с ней, как с вами, и пусть она приходит. А то вы бегаете с ней встречаться за угол, как говорит мне мое второе зрение”. Поскольку я действительно бегала и бегала именно за угол, чего Анна Андреевна никак не могла знать, этот маленький эпизод произвел на меня сильное впечатление, и я тут же записала монолог Ахматовой» (Ахматова 1991: 636-637).

Лосев Вячеслав Михайлович (1890-1942) - библиограф, краевед, сотрудник Института истории АН СССР в Ленинграде.

«Мемуары Лосева или “Еще один царскосел” (Ахматова 1996: 20). См. его работу: Литература о Детском селе / Сост. Голлербах Э. Ф., дополнил В. М. Лосев; под ред. О. Э. Вольценбурга. Л.: Ленинградское общество коллекционеров, 1933. «...в течение ряда лет был секретарем Общества “Старый Петербург - Новый Ленинград”. За короткое время своего пребывания в СБ и Э ЛОК В. М. Лосев сделал несколько <..> докладов, из которых наибольший интерес представляет “Книга в произведениях русских поэтов”. <...> По материалам В. М. Лосева оказывается, что с конца XVIII в. до 1917 г. в русской поэзии имеется до 60 произведений, либо полностью посвященных книге, либо содержащих высказывания о ней. С 1917 г. по 1932 г. их, по сведениям В. М. Лосева, свыше 30» (Берков 1971: 124-125).

Ср. также запись в его дневнике от 21 октября 1921 г.: «Вечером на вечере Анны Ахматовой в Доме Литераторов. Масса народу. Недурные по содержанию и по идейному настроению - прочитаны были весьма неважно: однотонно, натянуто и малоестественно. Сама также мало похожа на поэтессу - вроде стареющей и бурно 
пожившей актрисы, а платок (вроде шали) делал ее похожей на портниху» ${ }^{15}$.

В указателе туринского издания (см.: Ахматова 1996: 807) раскрыт ошибочно как Лев Лосев (псевдоним Алексея Владимировича Лифшица; 1937-2009). Ср. к слову воспоминания последнего: «Моя встреча с Ахматовой. Мне лет одиннадцать-двенадцать. В приемной лечебного отдела Литфонда, тогда еще в шереметевском особняке, окнами на Неву, мы с матерью сидим, ожидая очереди, ближе к двери. “Только сразу не смотри, - шепчет мама, - у окна Ахматова". Скашиваю глаза, вижу черный профиль, не очень чистое окно с толстым зеркальным стеклом, грязноватый лед Невы, длинную горизонталь Военно-медицинской академии на другом берегу» (Лосев 2000: 542).

Наша атрибуция, впрочем, предположительная.

Незвал (Nezval) Витезслав (1900-1958) - чешский поэт.

В составе «Книги переводов» (см.: Ахматова 1996: 388). Запись февраля-марта 1963 г.: «Незвал (выбрать переводы)» (Ахматова 1996: 307, 305, 441) - помимо четырех переведенных Ахматовой стихотворений - «Продавщица чудес», «Доброй ночи», «Ноктюрн», «Отдых», предполагалось к переводу стихотворение «Анданте» (см.: Ахматова 1996: 317). Переводы курировала В. А. Мартемьянова (см.: Ахматова 1996: 319).

10 мая 1963 г.: «Вспомнить Незвала: “Доброй ночи!”...» (Ахматова 1996: 321); см. перевод:

\section{Доброй ночи}

За шторами вечерний мрак стоит,

Вся выпита вода лимонная. Я слышу

Извозчиков ночных, далекий стук копыт.

Неповторимый день уходит в Лету.

Приветствую тебя, поэт. Минуту эту,

Ее звучание и блеск сумей поймать,

15 ОР РНБ. Ф. 443. № 15. Л. 95 об.; сообщено В. Н. Сажиным; Тименчик 1994: 10. 
Иначе для чего стихи твои мне знать?

(Голоса 1965: 55)

Ср. о неточном расчете составителей «Антологии чешской поэзии XIX-XX веков» (М.: ГИХЛ, 1959): Ахматовой был бы ближе Карел Томан, чем декларативный С. К. Нейман и авангардный Незвал: Parolek 1989: 252. Сама Ахматова, впрочем, находила его «парфюмерным» (см.: Найман 1999: 216).

Еще при жизни Ахматовой об этих ее переводах писали:

Сравнение ее перевода стихотворения «Отдых»с переводом молодого поэта Д. Бобышева показывает как раз диалектическую взаимосвязь точности перевода со свободой интерпретации. Перевод Д. Бобышева:

Однажды я проснулся темной ночью

В горах, далеко от ручьев и звезд.

Мне было так легко, как ходоку без ноши,

Который распевает и за город зовет.

И был я счастлив, будто вновь рожденный,

И палку выломал себе я у реки,

И шел я гордый, смелый, непреклонный,

Дыша глубоко и сжимая кулаки.

И свежий воздух, и сырые ароматы,

И мысли чистые, как звезды в марте, -

Алмазами сияли при луне.

Я был, как королевич, сошедший вдруг с кареты,

Который все искал красавицу с портрета

И вот нашел ее в ромашках и вине.

Перевод А. Ахматовой:

Проснулся я средь гор, где ночь в тиши застыла.

Колодцы и жилье - как звезды далеки.

И понял я бродяг - им в городах немило,

А здесь душа поет, и вновь шаги легки. 
Как после хвори злой, отрадно сердцу было.

Я веточку сорвал, ласкал ее листки,

Я шел, ведомый вдаль таинственною силой,

Шел, глубоко дыша и стиснув кулаки.

Среди росистых трав впивал я чистый воздух,

И мысли обрели кристальный свет, что в звездах

Морозной тишиной до блеска отгранен.

Низложенный король счастливей был едва ли,

Увидев на лугу при звуках пасторали

Пастушку, что встречал лишь на картинках он.

А теперь процитируем этот сонет в подстрочнике и посмотрим, насколько точнее передает А. Ахматова смысл и настроение подлинника, хотя одну из основных метафор она создает по-своему, руководствуясь иным поэтическим принципом. Подстрочник:

Однажды я проснулся глубокой ночью в горах, далеко от колодцев и звезд, и было мне хорошо, как бродяге, который начинает петь, как только поворачивается спиной к звону городов. Я был счастлив, как после болезни, и оторвал веточку от куста. Я шел, ведомый таинственной силой, дыша глубоко и сжимая кулаки. В этом чистом воздухе я пил свежие ароматы, которые дрожали, как алмазы, обмокнутые в луну. Мои мысли чистились, как звезды в мороз. И был я счастливее низложенного короля, который среди пастушек при звуках пасторали узнает пастушку, которую знал только по картинкам.

Совершенно необычный незваловский образ «ароматы, дрожавшие как алмазы, обмокнутые в луну», А. Ахматова просто-напросто опускает, зато следующий: «мои мысли чистились (можно понимать как “шлифовались до сверканья” или как “прояснялись”), как звезды в мороз», она передает, сохраняя и развивая оба значения, т. е. проявляет тем самым и свободу, и точность перевода, ибо в стихотворном переводе с одного языка на другой именно в этом выборочном принципе, дающем возможность 
передать силу произведения наиболее доступными переводчику средствами, и состоит секрет успеха (Николаева 1964: 214-215).

«Справедливости ради заметим, что ошибок, вызванных курьезами в подстрочных переводах, мало в обеих книгах, что делает честь автору подстрочников. Хочется указать на один - вопиющий. В великолепный перевод А. Ахматовой “Продавцы чудес" вкралась ошибка. Вместо “Продавщицы ядовитых грибов” ее героиня превращена в продавщицу “ядовитых губ”, видимо, по воле подстрочника, где чешское "hub" т. е. род. п. множ. ч. от “houby" грибы, оставлено без перевода» (Будагова 1965: 95).

Ср. также стихотворение Иосифа Бродского «Витезслав Незвал» (1961):

На Карловом мосту ты улыбнешься, переезжая к жизни еженощно вагончиками пражского трамвая, добра не зная, зла не забывая...

(Бродский 1992: 62).

Радимов Павел Александрович (1887-1967) - «Павел Радимов чл<ен> І-го Цеха поэтов (поэт-художник)» (Ахматова 1996: 725) - возможно, толчком к записи было сообщение в письме болгарской поэтессы Светланы Лиловой-Тихомировой от 10 мая 1965 г. из Москвы о том, как он накануне отрекомендовался членом Цеха: «Он очень тепло вспоминал Вас и просил передать Вам горячий привет. Какой же это талантище!» ${ }^{16}-$ П. Радимов перевел одно стихотворение, напечатанное рядом с переводом Ахматовой в газетной подборке С. Лиловой-Тихомировой «Новые стихи» (Литературная Россия. 1965. 13 августа). Основанием для автоаттестации был факт публикации его стихов в «Гиперборее» (1912. № 3. Сонеты Сорочьего базара: 1. Коровий торг («Базар гудит. Торгуют чем попало...»). 2. Сумерки («Промозглый вечер хрупкой пеленою...»). 3. Карусель («Кружится карусель. Петрушка визгом

16 ОР РНБ. Ф. 1073. № 1021. 
тонким...»). 4. Торговки («Ядреные, с румяными щеками...»); 1913. № 6. Токаревские элегии. 1. Перекресток («Здесь перекресток. Часовня стоит на зеленой лужайке...»). 2. Стойло («Тяжек полуденный зной, изливаемый небом жестоким...»)). Видимо, после этого сообщения имя его было внесено в список Цеха поэтов в рукописи «Листков из дневника» (этот вариант опубликован в: Ахматова 1989: 129). Список этого варианта «Листков из дневника» был сообщен в числе прочих первых читателей Е. С. Добину, у которого в рукописи книги об Ахматовой, которая планировалась к изданию в 1966 г. в ленинградском отделении издательства «Советский писателей», значилось: «Во главе “цеха поэтов" стояли “синдики” - Гумилев и Городецкий - и “стряпчий” Д. В. Кузьмин-Караваев, известный адвокат, муж поэтессы, вошедшей в “цех”. Кроме названных в Цех входили: М. Лозинский, Георгий Иванов, Георгий Адамович, В. В. Гиппиус, П. Радимов, В. Юнгер, Велимир Хлебников и др.» ${ }^{17}$.

Однако в списке Цеха, составленном в 1913-1914 гг. М. Л. Лозинским, его имени не было. Не упоминал и он своего членства в 1920-е годы, когда предоставлял биографические сведения: «Происходит из крестьян. Писать начал с 14 лет. Первое печатное выступление в 1912 г.» (Никитина 1926: 380). Этот факт не упомянут и в позднейшей благожелательной рецензии бывшего синдика Цеха поэтов: «Павел Радимов - Гомер нашей деревни. <...> Необычайный расцвет его поэзии (он работает уже давно, первая книга 1912 г.) именно в наши дни несомненно связан с подъемом середнячества. <...> Пока же надо быть ему благодарным и за то, что он, один из первых стал живописать деревню не с дворянской точки зрения, как делала вся наша классическая дворянская литература, а извнутри <sic!>, c задворков, с заднего крыльца избы. Вместе с Есениным, его книга дает богатый материал для работы в студиях ${ }^{18}$. Нет подобного

17 РГАЛИ. Ф. 2849. Оп. 1. Ед. хр. 19. Л. 26; в окончательной версии книги, вышедшей свет осенью 1968 г., в связи с истреблением имени Гумилева, исчез и этот список; подробнее о кастрации книги см.: Тименчик 2018: 451-453.

18 С. Г. [С. М. Городецкий]. Рец. на кн.: П. Радимов. Деревня. Казань, 1922. - Труд. 1922. № 79. 9 апреля; ср. его же рецензию на ту же книгу Радимова в «Печати и революции», где говорится, в частности, что «его “Попиада" войдет в классическую 
упоминания и в мемуарах П. Радимова; там, между прочим, рассказывается, что во время операции, которую делал ему знаменитый хирург С. С. Юдин, тот читал стихи Ахматовой (см.: Радимов 1973: 109).

Гумилев дважды писал о стихах П. Радимова (см.: Гумилев 1990: $145,184-185,319)$, сравнивая его с Франсисом Жаммом. Имя его впоследствии было широко известно массовому советскому читателю по стихотворению Маяковского «Четырехэтажная халтура» (1926):

О, сколько нуди такой городимо, от которой

мухи падают замертво!

Чего только стоит

один Радимов

с греко-рязанским своим гекзаметром!

(Маяковский 1957: 114; также см. примечания на стр. 495-497)

Ср. воспоминания о позднем Радимове:

Полный, седовласый, розовощекий, он был похож на повеселевшего врубелевского Пана с голубыми хмельными глазами.

Он не выговаривал букву «р» и перед чтением стихов обратился к слушателям с такой речью:

- Доягие дъюзья! Я - стаый художник, встьечался и дъюжил со многими коллегами, в том числе с Ильей Ефимовичем Епиным. Он очень хоёшо отзывался и о моих стихах, и о кайтинах. Был знаком с Владимиом Маяковским. Это он обо мне даже стихи написал:

От Ядимовского гекзаметьа

Мухи падают замейтва.

Публика оживилась, заулыбалась, а Павел Александрович продолжал:

- Это ничево... да... Он обо мне и лучше говоил... А тепей - стихи:

русскую литературу» (Городецкий 1922: 46), но опять-таки нет ни слова о членстве в Цехе поэтов. 
Деевья в инее, а снега вовсе нет.

Зима задумалась у столбовой доёги.

Ядимов Павел я, художник и поэт,

Советский гъяжданин и человек нестьёгий...

(Старшинов 1996: 16).

См. о нем: Блинкина 2007: 236-237; Лекманов 2000: 32-34; Соболева 2016: 172-182.

Тараховская Елизавета Яковлевна (ур. Парнох; 1895-1968) поэтесса.

«В Ташкенте Тараховская (детская писательница, сестра C. Парнок, кот<орая> надписала мне книгу:

Под крышей дома бесноватого

Живет звезда моя Ахматова,

мы жили - ул. К. Маркса, 7, общежитие м<осковских> писателей), бывшая бестужевка, вспоминала, что была на этом вечере [25 ноября 1913 г. на Высших женских курсах. - P. T.] и запомнила меня. Тогда мы думали, что никогда не увидим [тех] ни $\mathrm{B}<$ асильевского> О<строва>, ни тех с кем были разлучены» (Ахматова 1996: 622).

См. поздравительную телеграмму Е. Я. Тараховской из Малеевки 25 июня 1959 г. (ОР РНБ, Ф. 1073. № 1591). Ср. в ее автобиографических набросках: «Когда я вспоминаю покойную Марину Цветаеву и недавно умершую Анну Ахматову, тоже замечательную поэтессу, то первая (т. е. Марина) кажется мне яркой молнией, а вторая тихой лампадой, а их обеих, лучших русских поэтесс, травили и довели до гибели. А обе они были настоящим и русскими патриотками. К счастью, позднее Ахматова получила докторскую степень в Лондоне, а затем какую-то премию в Италии. Таким образом, она хотя бы перед смертью нашла должное признание» ${ }^{19}$.

См. также: Приходько 1996: 20-21; [Б. п.] 1997: 137-138. 19 Приходько В. Елизавета Тараховская: Грех «легкомыслия», или на долю Марины
Цветаевой выпало слово «плаха». - Московская правда. 1996. № 157. 30 августа. 
Черняк Яков Захарович (1898-1955) - литературовед. Выписки из его дневника о встречах с Ахматовой в Ташкенте в 1942 г. (впервые: Ахматова 1991: 375-377) называются в нескольких планах подборок материалов о «Поэме без героя» (см.: Ахматова 1996: 238, 451, $532,608)$. Ахматова получила их от его вдовы Елизаветы Черняк (ур. Тубиной ) (1899-1971) (ОР РНБ. Ф. 1073. № 1045).

Я. 3. Черняк, в частности, записал:

Здесь Анна Ахматова. К ней паломничество.

В. Волькенштейн <...> жалуется:

- Люди идут к ней стаями; она вывешивает записку на двери: работаю. Не помогает. - Это выражение любви не кажется ему искренним: идут, потому что Ахматова в чести, признана властью, кажется влиятельной.

Артистка Ф. Раневская рассказала: записки с ее двери исчезают, потому что - автограф.

Ахматова человек исключительной духовности, строгости, чистоты. От всех благ и преимуществ, щедро предлагаемых ей местным руководством, отказывается. <...> Живет намеренно трудно.

Поза? Нет, схима. <...>

Какой поэт! Весь в музыке, в сдержанной музыке, которой искусаны губы, измучены прекрасные руки. Сдержанный, закованный порыв. Извержение, остановленное чеканщиком. Читала поэму «1913 год, или Поэма без героя». <...> Тема - спор с временем $<\ldots>$. Эта поэма - о том, как жизнь шла вне жизни и становилась трагическим звуком.

Еремин говорит: как старинная постройка - с башенками, пристройками, балконами. Нет - как лирические поэмы Байрона. Как первые - байронические - Пушкина. Вместо сюжета - музыкальные наплывы, боренье тем - желающих вместиться в лирику, вернуться к ней. Удивительным является возвращение к этому - в позднем творчестве (Ахматова 1991: 375-376).

Упоминаемый в этой записи писатель Дмитрий Иванович Еремин (1904-1993) спустя 47 лет пометил на полях статьи О. Крупенье 
«Ахматова в Ташкенте» (Литературная газета. 1989. 3 мая): «Когда я у нее был, с ней были вдова Мандельштама и арт<истка $>$ Фаина Георгиевна Раневская. Д. Е.» ${ }^{20}$. В его бумагах сохранилось его неопубликованное стихотворение:

\section{А. А. Ахматовой}

Этот голос певуч и робок;

Эти брови, как очерк скобок,

Замыкающих тень ресниц;

На невянущих пальцах перстни,

На душе - золотые песни,

Голос [прежних] давних [любовных] [весенних] крылатых птиц.

Я не слышал ее ни разу,

Ни стихов, ни простую фразу.

А услышав, сказал, шутя:

- Здесь, под небом Узбекистана,

Вы, как прежде, - «Святая Анна»,

Многогрешница и дитя!

Ваше слово, как [мед] встарь, весомо;

С Вами самый бездомный - дома...

Я не знал Вас, и вот, узнав,

Сразу понял: Вы - синь над морем,

Вы, как радость в обнимку с горем,

Как извечная зелень трав!

Пусть морщина [лежит] остра, как ранка:

Это вспомнилась Вам Фонтанка,

Питер [старых] прежних далеких лет.

Но Вы - новая, молодая!

Не печальте себя, гадая:

Вы - товарищ, боец, поэт!

20 РГАЛИ, Ф. 3230. Оп. 1. Ед. хр. 270. 
Пусть на пальцах мерцанье перстней, -

Славьте мир своей доброй песней!

Крепче голос и шире круг!

[Голос песен] Мир поэта - красив и громок,

И ему подпоет потомок,

Называя Вас кратко: друг.

14 VII $42^{21}$

Помета: «В июле 1942 г. я был у Анны Андреевны в гостях, в ее проходной ташкентской комнате. Она была нездорова, картинно лежала в белой тунике на диване-постели и читала мне свою поэму “1913 год”. В результате этого посещения, беседы и чтения - и появились мои стихи... Д. Е.»22.

О письме Я. З. Черняка И. В. Сталину в защиту Ахматовой в сентябре 1946 г. см. в статье С. Шумихина в «Независимой газете» за 5 марта 1996 года ${ }^{23}$. О двух выходах Д. И. Еремина на авансцену литературного процесса - нападках на альманах «Литературная Москва» (“тихий, безликий “неизвестный писатель”, как его тогда называли») см.: Свирский 1979: 199; а о его статье «Перевертыши» по делу А. Синявского и Ю. Даниэля, когда А. Твардовский в дневнике назвал его «дураком и мерзавцем», см.: Тименчик 2014: 492, 613; ср. характерный анекдот: «Властное признание и Сталинскую премию он обрел еще в самом начале пятидесятых. За роман "Гроза над Римом”, яростно обличавший Ватикан за благословение фашизма и сотрудничество с Муссолини. В Италии, правда, автор не бывал, но книжка и там его прославила. Ватиканский еженедельник публиковал из номера в номер перевод - без комментариев. Знакомая славистка рассказывала мне, что итальянцы хохотали, будто ничего смешнее отродясь не читывали» (Перельмутер 2015: 66-67). См. о нем главу «Поддержанный Сталиным надсмотрщик: Дмитрий Еремин» (см.: Огрызко 2018: 812-823).

21 РГАЛИ. Ф. 3230. Оп. 1. Ед. хр. 57. Л. 9.

22 РГАЛИ. Ф. 3230. Оп. 1. Ед. хр. 57. Л. 9.

23 Шумихин С. «Здесь мы узнали простые и важные вещи»: Яков Черняк об Анне Ахматовой. - Независимая газета. 1996. № 43.5 марта. 


\section{БИБЛИОГРАФИЯ}

Адамович Г. 2001. Бунин. Воспоминания. - И. А. Бунин: Pro et contra. Личность и творчество Ивана Бунина в оценке русских и зарубежных мыслителей и исследователей. Антология. СПб.: РХГИ. С. 216-236.

Александров Р. [А. Ю. Розенбойм] 2002. Истории «с раньшего времени»? Очерки. Одесса: Оптимум.

Анненский И. 1979. Книги отражений / Издание подготовили Н. Т. Ашимбаева, И. И. Подольская, А. В. Федоров. М.: Наука.

Ауслендер С. 1913. Театры. - Аполлон. № 2. С. 65-67.

Ахматова А.1968 Соч.: В 2-х тт. / Вступительная ст. Г. П. Струве и Б. А. Филиппова. 2-е издание, пересмотренное и дополненное. Т. 2. [Мюнхен]: Международное литературное содружество.

Ахматова А. 1989. Requiem / Сост. и примечания Р. Д. Тименчика при участии К. М. Поливанова. М.: Издательство МПИ.

Ахматова А. 1991. Воспоминания об Анне Ахматовой / Сост. В. Я. Виленкин, В. А. Черных. М.: Советский писатель.

Ахматова А. 1996. Записные книжки (1958-1966) / [Сост. и подготовка текста К. Н. Суворовой; вступительная ст. Э. Г. Герштейн; научное консультирование, вводные заметки к записным книжкам, указатели В. А. Черных.] М.; Torino: Giulio Einaudi editore.

[Б. п.] 1929. Ни БСЭ, ни ЛЭ. - Чудак. № 19. С. 11.

[Б. п.] 1997. Тараховская Е. Я. - Российская еврейская энциклопедия. Т. 3: Биографии. С - Я. М.: Российская Академия Естественных Наук; Научный фонд «Еврейская энциклопедия»; «ЭПОС». С. 137-138.

Баран Г. 1974. Письма А. А. Ахматовой к Н. И. Харджиеву. - Russian Literature. Vol. 3. Issues 2-3. C. 5-17.

Берков П. Н. 1971. История советского библиофильства. М.: Книга.

Блинкина О. Е. 2007. Радимов Павел Александрович. - Русские писатели: 1800-1917. Биографический словарь. Т. 5: П - С. М.: Научное издательство «Большая российская энциклопедия». С. 236-237.

Бродский И. 1992. Соч.: В 4-х томах. Т. 1. СПб., еtс.: Пушкинский фонд; Третья волна.

Будагова Л. Н. 1965. О переводах поэзии Витезслава Незвала на русском языке. - Советское славяноведение. № 4. С. 82-96.

Бунин И. 1950. Воспоминания. Париж: Возрождение.

Голоса 1965. Голоса поэтов: Стихи зарубежных поэтов в переводе Анны Ахматовой. М.: Издательство „Прогресс”. 
Городецкий С. 1922. Обзор областной поэзии. - Печать и революция. Кн. 8 (ноябрь - декабрь). М.: Государственное издательство. С. 44-48.

Гранин Д. А. 2010. Причуды моей памяти: Книга-размышление. М.; СПб.: Центрполиграф.

Гумилев Н. 1990. Письма о русской поэзии / [Сост. Г. М. Фридлендер (при участии Р. Д. Тименчика); вступительная ст. Г. М. Фридлендера; подготовка текста и комментарии Р. Д. Тименчика]. М.: Современник.

Двинятина Т. М. 2001. Поэзия Ивана Бунина и акмеизм: Заметки к теме. - И. А. Бунин: Pro et contra. Личность и творчество Ивана Бунина в оценке русских и зарубежных мыслителей и исследователей: Антология. СПб.: РХГИ. С. 518-543.

Дувакин В. Д., Радзишевский В. В. 2017. Беседы с Виктором Шкловским. Воспоминания о Маяковском. М.: Common Place; Устная история.

Евстигнеева А. Л. 1989. Литературное наследие А. А. Ахматовой в ЦГАЛИ СССР. - Советские архивы. № 5. С. 53-55.

Ильин Н. 1990. Из воспоминаний библиотекаря / Публикация, предисловие комментарии С. Шумихина. - Альманах библиофила. Вып. 27. М.: Книга. С. 262-296.

Катаев В. 1972. Трава забвения. - Катаев В. Собр. соч.: В 9-ти тт. Т. 9. М.: Художественная литература. С. 249-448.

Королева Н. Г. 1978. Сто альбомов (Коллекция А. Е. Крученых). - Встречи с прошлым. Вып. 3. М.: Советская Россия. С. 294-305.

Коряков М. 1947. В Ясной Поляне. - За свободу. Нью-Йорк. № 18. С. 82-99. Кочур Г. 1997. Мои воспоминания о Елене Алексеевне Ильзен. - Воля. № 6-7. С. $370-371$.

Кралин М. 2002. «Двух голосов перекличка»: Иван Бунин и Анна Ахматова. - Наш современник. № 6. С. 258-282.

Крученых А. 1922. Сдвигология русского стиха: Трахтат обижальный (Трактат обижальный и поучальный). Кн. 121-ая. М.: [б. и.].

Крученых А. 1923. Фактура слова: Декларация. Кн. 120 -ая. М.: [б. и.].

Крученых А. 1930а. Живой Маяковский: Разговоры Маяковского. Вып. 1. М.: Изд. группы друзей Маяковского.

Крученых А. 1930b. Живой Маяковский: Разговоры Маяковского. Вып. 3 М.: Изд. группы друзей Маяковского.

Крученых А. Е. 1990. Письма к И. М. Зданевичу / Предисловие, публикация и примечания Марцио Марцадури. - Русский литературный 
авангард: Материалы и исследования / Под ред. Марцио Марцадури, Даниелы Рицци и Михаила Евзлина. [Trento]: Департамент Истории Европейской Цивилизации, Университет Тренто. С. 129-146.

Крученых А. 1992. Кукиш прошлякам. М.; Таллинн: Гилея.

Крученых А. 1999. Память теперь многое разворачивает: Из литературного наследия Кручёных / Сост., послесловие, публикация текстов и комментарии к ним Н. Гурьяновой. [Oakland]: Berkeley Slavic Specialties.

Крученых А. 2002. Стихи из машинописного собрания 1943 г. «Московские встречи» / Публикация и предисловие Е. Арензона. - Футурум АРТ. № 4 [URL: http://www.futurum-art.ru/archiv/4_2002/kruch.htm].

Кузин Б. С. 1999. Воспоминания. Произведения. Переписка. Мандельштам Н. Я. 192 Письма к Б. С. Кузину / Подготовка текстов, примечания и комментарии Н. И. Крайневой и Е. А. Пережогиной. СПб.: ИНАПРЕСС. Лекманов О. А. 2000. Книга об акмеизме и другие работы. Томск: Водолей. Либединская Л. 2000. «Зеленая лампа» и многое другое. М.: Радуга.

Лосев Л. 2000. Собранное: Стихи. Проза. Екатеринбург: У-Фактория.

Лукницкий П. Н. 1997. Acumiana: Встречи с Анной Ахматовой. Т. II: 19261927. М.: Русский путь.

Мандрыкина Л. А. 1979. Из рукописного наследия А. А. Ахматовой. - Нева. № 6. С. 196-200.

Мароши В. В. 2000. Имя автора (историко-типологические аспекты экспрессивности). Новосибирск: Издательство Новосибирского университета.

Маяковский В. В. 1957. Полн. собр. соч.: В 13-ти тт. Т. 7: Стихотворения второй половины 1925 года - 1926 года и очерки об Америке. М.: Государственное издательство художественной литературы.

Найман А. 1999. Рассказы о Анне Ахматовой. М.: Вагриус.

Никитина Е. Ф. 1926. Русская литература от символизма до наших дней: Литературно-социологический семинарий / Предисловие Н. К. Пиксанова. М.: Никитинские субботники.

Николаева Н. 1964. Незвал в русских переводах. - Чехословацко-советские литературные связи. М.: Наука. С. 182-215.

Огрызко В. 2018. Советский литературный генералитет: Судбы и книги. M:. Литературная Россия.

Одоевцева И. 1988. На берегах Невы. М.: Художественная литература. 
Оцуп Н. 1993. Океан времени: Стихотворения, дневник в стихах, статьи и воспоминания о писателях / Сост., вступительная ст. и подготовка текста Л. Аллена; комментарии Р. Тименчика. СПб.; Дюссельдорф: Logos; Голубой всадник.

Пастернак Б. Л. 2005. Полн. собр. соч.: В 11-ти тт. Т. 9: Письма 1935-1953. М.: Слово/Slovo.

Перельмутер В. 2015. Записки без комментариев (II). - Арион. № 2. С. 60-77. Перцова Н. 1995. Словарь неологизмов Велимира Хлебникова. Wien; M.: [б. и.].

Приходько В. 1996. [Елизавета Тараховская]. - Детская литература. № 4/6. C. 20-21.

Пушкин А. К. 1990. «Мирсконца» (Из архива А. Е. Крученых: Стихи, воспоминания, письма Б.Л. Пастернака). - Встречи с прошлым. Вып. 7. М.: Советская Россия. С. 497-524.

Радимов П. 1973. О родном и близком. Воспоминания. М.: Московский рабочий.

Свирский Г. 1979. На лобном месте. Литература нравственного сопротивления (1946-1976 гг.). Лондон: Overseas Publications Interchange.

Сетницкая О. 1990. Встречи с Алексеем Крученых (из дневниковых записей). - Русский литературный авангард: Материалы и исследования / Под ред. Марцио Марцадури, Даниелы Рицци и Михаила Евзлина. [Trento]: Департамент Истории Европейской Цивилизации, Университет Тренто. С. 151-199.

Соболева А. 2016. «Попиада» Радимова среди гекзаметров начала XX века. - Русская филология: Сборник научных работ молодых филологов. [Вып.] 27. Тарту: Тартуский университет. С. 172-182 [URL: http:// dspace.ut.ee/handle/10062/51216].

Старшинов Н. К. 1996. Лица, лики и личины: Литературные мемуары. М.: РИФ «РОИџ.

Тименчик Р. 1994. Из латвийской ахматовианы. - Даугава. № 6. С. 3-19.

Тименчик Р. 2006. Тименчик Р. Из Именного указателя к «Записным книжкам» Ахматовой. - Анна Ахматова: Эпоха, судьба, творчество: Крымский Ахматовский научный сборник. Вып. 4. Симферополь: Крымский Архив. С. 142-180.

Тименчик Р. 2008. Что вдруг: Статьи о русской литературе прошлого века. Иерусалим; М.: Гешарим; Мосты культуры. 
Тименчик Р. 2010. Из Именного указателя к «Записным книжкам» Ахматовой (К вопросу о технических проблемах комментирования). Лесная школа: Труды VI Международной летней школы на Карельском перешейке по русской литературе. Поселок Поляны (Уусикирко) Ленинградской области: [б. и.]. С. 143-172.

Тименчик Р. 2014. Последний поэт: Анна Ахматова в 1960-е годы. Иерусалим; М.: Гешарим; Мосты культуры.

Тименчик Р. 2018. История культа Гумилева. М.: Мосты культуры.

Тутова-Сенькина Ю. 1994. Мой сосед. - Алексей Крученых в свидетельствах современников / Сост., вступительная ст., подготовка текста и комментарии Сергея Сухопарова. München: Verlag Otto Sagner. C. $136-141$.

Флаттеров И. [А. И. Добкин] 1979. К биографии О. Э. Мандельштама: Переписка В. Д. Бонч-Бруевича с О. Э. Мандельштамом. - Память: Исторический сборник. Вып. 2. Париж: YMCA-Press. C. 432-437.

Фрезинский Б. 2013. Об Илье Эренбурге: Книги. Люди. Страны. М.: Новое литературное обозрение.

Хлебников В. 1930. Собр. произведений. T. IV: Проза и драматические произведения. Л.: Издательство писателей в Ленинграде.

Хлебников В. 1940. Неизданные произведения: Поэмы и стихи. М.: Гослитиздат.

Черных В. 2016. Летопись жизни и творчества Анны Ахматовой: 1889-1966. Издание третье, исправленное и дополненное. М.: Азбуковник.

Чуковская Л. 1997а. Записки об Анне Ахматовой. Т. 1: 1938-1941. М.: Согласие.

Чуковская Л. 1997b. Записки об Анне Ахматовой. Т. 2: 1952-1962. М.: Согласие.

Шелаева А.А. 1996. Петербургский литератор Вильгельм Зоргенфрей. Гумилевские чтения: Материалы международной конференции. СПб.: Санкт-Петербургский гуманитарный университет профсоюзов. С. 254-263.

Эренбург И. 1922. Русская поэзия. - Вещь. Берлин. № 1-2. С. 8-9 (подпись: Жан Сало).

Parolek, R. 1989. Anna Achmatovová jako překladetelka. - Československá rusistica. Roč. XXXIV. Č. 5. S. 249-253. 


\section{REFERENCES}

Adamovich, G. 2001. "Bunin. Vospominaniia.” In I. A. Bunin: Pro et contra. Lichnost' i tvorchestvo Ivana Bunina v otsenke russkikh i zarubezhnykh myslitelei i issledovatelei. Antologiia, 216-36. Saint-Petersburg: RKhGI.

Akhmatova, A. Requiem. Compiled and annotated by R. D. Timenchik with the assistance of K. M. Polivanov. Moscow: Izdatel'stvo MPI, 1989.

—. Zapisnye knizhki (1958-1966). Moscow and Turin: Giulio Einaudi editore, 1996.

- Sochineniia. Introduction by G. P. Struve and B. A. Filippov. 2nd ed., rev. and exp. 2 vols. Vol. 2. [Munich]: Mezhdunarodnoe literaturnoe sodruzhestvo, 1968.

Aleksandrov, R. [A. Iu. Rozenboim, pseud.] Istorii "s ran'shego vremeni"? Ocherki. Odessa: Optimum, 2002.

Annenskii, I. Knigi otrazhenii. Moscow: Nauka, 1979.

Auslender, S. Teatry. Apollon 2 (1913): 65-67.

Baran, H. "Pis'ma A. A. Akhmatovoi k N. I. Khardzhievu." Russian Literature 3, no. 2-3 (1974): 5-17.

Berkov, P. N. Istoriia sovetskogo bibliofil'stva. Moscow: Kniga, 1971.

Blinkina, O. E. “Radimov Pavel Aleksandrovich.” In Russkie pisateli: 1800-1917. Biograficheskii slovar'. Vol. 5, P-S, 236-37. Moscow: Nauchnoe izdatel'stvo "Bol'shaia rossiiskaia entsiklopediia", 2007.

Brodskii, I. Sochineniia. 4 vols. Vol. 1. Saint-Petersburg, etc.: Pushkinskii fond \& Tret'ia volna, 1992.

Budagova, L. N. “O perevodakh poezii Vítězslava Nezvala na russkom iazyke.” Sovetskoe slavianovedenie 4 (1965): 82-96.

Bunin, I. Vospominaniia. Paris: Vozrozhdenie, 1950.

Duvakin, V. D. and Radzishevskii, V. V. Besedy s Viktorom Shklovskim. Vospominaniia o Maiakovskom. Moscow: Common Place \& Ustnaia istoriia, 2017.

Dviniatina, T. M. “Poeziia Ivana Bunina i akmeizm: Zametki k teme.” In I. A. Bunin: Pro et contra. Lichnost' $i$ tvorchestvo Ivana Bunina $v$ otsenke russkikh i zarubezhnykh myslitelei i issledovatelei: Antologiia, 518-43. SaintPetersburg: RKhGI, 2001.

Ehrenburg, I. “Russkaia poeziia.” Veshch' 1-2 (April-May 1922): 8-9.

Evstigneeva, A. L. "Literaturnoe nasledie A. A. Akhmatovoi v TsGALI SSSR." Sovetskie arkhivy 5 (1989): 53-55. 
Flatterov, I. [A. I. Dobkin, pseud.] "K biografii O. E. Mandel'shtama: Perepiska V. D. Bonch-Bruevicha s O. E. Mandel'shtamom.” In Pamiat': Istoricheskii sbornik. Vol. 2, 432-37. Paris: YMCA-Press, 1979.

Frezinskii, B. Ob Il'e Erenburge: Knigi. Liudi. Strany. Moscow: Novoe literaturnoe obozrenie, 2013.

Golosa poetov: Stikhi zarubezhnykh poetov v perevode Anny Akhmatovoi. Moscow: Izdatel'stvo “Progress”, 1965.

Gorodetskii, S. “Obzor oblastnoi poezii.” Pechat' i revoliutsiia. Bk. 8 (November - December), 44-48. Moscow: Gosudarstvennoe izdatel'stvo, 1922.

Granin, D. A. Prichudy moei pamiati: Kniga-razmyshlenie. Moscow and SaintPetersburg: Tsentrpoligraf, 2010.

Gumilev, N. Pis'ma o russkoi poezii. Compiled by G. M. Fridlender with the assistance of R. D. Timenchik. Foreword by G. M. Fridlender. Annotated by R. D. Timenchik. Moscow: Sovremennik, 1990.

Chernykh, V. Letopis' zhizni i tvorchestva Anny Akhmatovoi: 1889-1966. 3rd ed., rev. and exp. Moscow: Azbukovnik, 2016.

Chukovskaia, L. Zapiski ob Anne Akhmatovoi. 2 vols. Moscow: Soglasie, 1997.

Il'in, N. "Iz vospominanii bibliotekaria." Published and annotated by S. Shumikhin. In Al'manakh bibliofila. Vol. 27, 262-96. Moscow: Kniga, 1990.

Kataev, V. Trava zabveniia. In Sobranie sochinenii. 9 vols. Vol. 9, 249-448. Moscow: Khudozhestvennaia literatura, 1972.

Khlebnikov, V. Sobranie proizvedenii. Vol. 4, Proza i dramaticheskie proizvedeniia. Leningrad: Izdatel'stvo pisatelei v Leningrade, 1930.

—. Neizdannye proizvedeniia: Poemy i stikhi. Moscow: Goslitizdat, 1940.

Kochur, G. “Moi vospominaniia o Elene Alekseevne Il'zen.” Volia 6-7 (1997): $370-71$.

Koriakov, M. “V Iasnoi Poliane.” Za svobodu 18 (1947): 82-99.

Koroleva, N. G. "Sto al'bomov (Kollektsiia A. E. Kruchenykh)." In Vstrechi s proshlym. Vol. 3, 294-305. Moscow: Sovetskaia Rossiia, 1978.

Kralin, M. “'Dvukh golosov pereklichka': Ivan Bunin i Anna Akhmatova.” Nash sovremennik 6 (2002): 258-82.

Kruchenykh, A. Sdvigologiia russkogo stikha: Trakhtat obizhal'nyi (Traktat obizhal'nyi i pouchal'nyi). Kniga 121-aia. Moscow: [n. p.], 1922.

—. Faktura slova: Deklaratsiia. Kniga 120-aia. Moscow: [n. p.], 1923.

—. Zhivoi Maiakovskii: Razgovory Maiakovskogo. Vol. 1. Moscow: Izd. gruppy druzei Maiakovskogo, 1930. 
—. Zhivoi Maiakovskii: Razgovory Maiakovskogo. Vol. 3 Moscow: Izd. gruppy druzei Maiakovskogo, 1930.

—. Kukish proshliakam. Moscow and Tallinn: Gileia, 1992.

- Pamiat' teper' mnogoe razvorachivaet: Iz literaturnogo naslediia Kruchenykh. Published, compiled and annotated by N. Gur'ianova. [Oakland]: Berkeley Slavic Specialties, 1999.

_. "Stikhi iz mashinopisnogo sobraniia 1943 g. Moskovskie vstrechi”. Published by E. Arenzon. - Futurum ART 4 (2002). Accessed October 31, 2018. http:// www.futurum-art.ru/archiv/4_2002/kruch.htm.

—. "Pis'ma k I. M. Zdanevichu”. Published and annotated by Marzio Marzaduri. In Russkii literaturnyi avangard: Materialy i issledovaniia. Edited by Marzio Marzaduri, Daniela Rizzi and Mikhail Evzlin, 129-146. [Trento]: Departament Istorii Evropeiskoi Tsivilizatsii, Universitet Trento, 1990.

Kuzin, B. S. Vospominaniia. Proizvedeniia. Perepiska. Mandel'shtam N. Ia. 192 Pis'ma k B. S. Kuzinu. Edited and annotated by N. I. Kraineva and E. A. Perezhogina. Saint-Petersburg: INAPRESS, 1999.

Lekmanov, O. A. Kniga ob akmeizme i drugie raboty. Tomsk: Vodolei, 2000.

Libedinskaia, L. “Zelenaia lampa” i mnogoe drugoe. Moscow: Raduga, 2000.

Losev, L. Sobrannoe: Stikhi. Proza. Ekaterinburg: U-Faktoriia, 2000.

Luknitskii, P. N. Acumiana: Vstrechi s Annoi Akhmatovoi. Vol. 2, 1926-1927. Moscow: Russkii put'.

Maiakovskii, V. V. Polnoe sobranie sochinenii. 13 vols. Vol. 7, Stikhotvoreniia vtoroi poloviny 1925 goda - 1926 goda i ocherki ob Amerike. Moscow: Gosudarstvennoe izdatel'stvo khudozhestvennoi literatury, 1957.

Mandrykina, L. A. "Iz rukopisnogo naslediia A. A. Akhmatovoi." Neva 6 (1979): 196-200.

Maroshi, V. V. Imia avtora (istoriko-tipologicheskie aspekty ekspressivnosti). Novosibirsk: Izdatel'stvo Novosibirskogo universiteta, 2000.

Naiman, A. Rasskazy o Anne Akhmatovoi. Moscow: Vagrius, 1999.

“Ni BSE, ni LE." Chudak 19 (1929): 11.

Nikitina, E. F. Russkaia literatura ot simvolizma do nashikh dnei: Literaturnosotsiologicheskii seminarii. Preface by N. K. Piksanov. Moscow: Nikitinskie subbotniki, 1926.

Nikolaeva, N. “Nezval v russkikh perevodakh.” Chekhoslovatsko-sovetskie literaturnye sviazi, 182-215. Moscow: Nauka, 1964. 
Odoevtseva, I. Na beregakh Nevy. Moscow: Khudozhestvennaia literatura, 1988. Ogryzko, V. Sovetskii literaturnyi generatitet: Sud'by i knigi. Moscow: Litaraturnaia Rossiia, 2018.

Otsup, N. Okean vremeni: Stikhotvoreniia, dnevnik $v$ stikhakh, stat'i $i$ vospominaniia o pisateliakh. Compiled and edited by L. Allen. Annotated by R. Timenchik. Saint-Peterbsburg and Düsseldorf: Logos \& Goluboi vsadnik, 1993.

Parolek, R. “Anna Achmatovová jako překladetelka.” Československá rusistica 24, no. 5 (1989): 249-53.

Pasternak, B. L. Polnoe sobranie sochinenii. 11 vols. Vol. 9, Pis'ma 1935-1953. Moscow: Slovo/Slovo, 2005.

Perel'muter, V. “Zapiski bez kommentariev (II).” Arion 2 (2015): 60-77.

Pertsova, N. Slovar' neologizmov Velimira Khlebnikova. Wien and Moscow: [n. p.], 1995.

Prikhod'ko, V. [Elizaveta Tarakhovskaia]. Detskaia literatura 4/6 (1996): 20-21.

Pushkin, A. K. "Mirskontsa (Iz arkhiva A. E. Kruchenykh: Stikhi, vospominaniia, pis'ma B. L. Pasternaka).” In Vstrechi s proshlym. Vol. 7, 497-524. Moscow: Sovetskaia Rossiia, 1990.

Radimov, P. O rodnom i blizkom. Vospominaniia. Moscow: Moskovskii rabochii, 1973.

Setnitskaia, O. "Vstrechi s Alekseem Kruchenykh (iz dnevnikovykh zapisei)." In Russkii literaturnyi avangard: Materialy $i$ issledovaniia. Edited by Marzio Marzaduri, Daniela Rizzi and Mikhail Evzlin, 151-199. [Trento]: Departament Istorii Evropeiskoi Tsivilizatsii, Universitet Trento, 1990.

Shelaeva, A. A. "Peterburgskii literator Wilhelm Sorgenfrei." In Gumilevskie chteniia: Materialy mezhdunarodnoi konferentsii, 254-63. Saint-Petersburg: Sankt-Peterburgskii gumanitarnyi universitet profsoiuzov, 1996.

Soboleva, A. "Popiada Radimova sredi gekzametrov nachala XX veka." Russkaia filologiia: Sbornik nauchnykh rabot molodykh filologov. Vol. 27, 172-82. Tartu: Tartuskii universitet, 2016. Accessed October 31, 20018. http://dspace.ut.ee/handle/10062/51216.

Starshinov, N. K. Litsa, liki i lichiny: Literaturnye memuary. Moscow: RIF "ROI”, 1996.

Svirskii, G. Na lobnom meste. Literatura nravstvennogo soprotivleniia (19461976 gg.). London: Overseas Publications Interchange, 1979. 
“Tarakhovskaia E. Ia.” Rossiiskaia evreiskaia entsiklopediia. Vol. 3, Biografii. S Ia, 137-38. Moscow: Rossiiskaia Akademiia Estestvennykh Nauk, Nauchnyi fond "Evreiskaia entsiklopediia" \& "EPOS", 1997.

Timenchik, R. “Iz latviiskoi akhmatoviany." Daugava 6 (1994): 3-19.

_. "Iz Imennogo ukazatelia k 'Zapisnym knizhkam' Akhmatovoi.” In Anna Akhmatova: Epokha, sud'ba, tvorchestvo: Krymskii Akhmatovskii nauchnyi sbornik. Vol. 4, 142-80. Sympheropolis: Krymskii Arkhiv, 2006.

- Chto vdrug: Stat'i o russkoi literature proshlogo veka. Jerusalem and Moscow: Gesharim \& Mosty kul’tury, 2008.

_. . 'Iz Imennogo ukazatelia k 'Zapisnym knizhkam' Akhmatovoi (K voprosu o tekhnicheskikh problemakh kommentirovaniia)." In Lesnaia shkola: Trudy VI Mezhdunarodnoi letnei shkoly na Karel'skom peresheike po russkoi literature, 143-72. Poliany (Uusikirko), Leningrad Oblast: [n. p.], 2010.

—. Poslednii poet: Anna Akhmatova v 1960-e gody. Jerusalem and Moscow: Gesharim \& Mosty kul'tury, 2014.

—. Istoriia kul'ta Gumileva. Moscow: Mosty kul'tury, 2018.

Tutova-Sen'kina, Iu. “Moi sosed.” In Aleksei Kruchenykh v svidetel'stvakh sovremennikov. Compiled and annotated by Sergei Sukhoparov, 136-141. Munich: Verlag Otto Sagner, 1994.

Vospominaniia ob Anne Akhmatovoi. Compiled by V. Ia. Vilenkin, V. A. Chernykh. Moscow: Sovetskii pisatel', 1991. 